\title{
El primer registro de Simón Fernández de Moya, escribano público de Cuenca. 1423
}

\author{
Francisco A. Chacón Gómez-Monedero \\ Universidad Autónoma de Madrid
}

\begin{abstract}
RESUMEN
El estudio y publicación de los registros notariales de la Edad Media proporciona interesante información sobre aspectos sociales de los habitantes de cualquier población. En este trabajo estudiamos el primer registro que confeccionó el escribano Simón Fernández de Moya, investido de la "fides pública» por el Concejo de Cuenca en sesión municipal de 7 de mayo de 1423. Se presta especial atención a los dos aspectos básicos que inieresan al diplomatista: el de los caracteres externos e internos, según la tipología diplomática de los negocios que fedata el "auctor». Ante la imposibilidad material de transcribir el Registro hemos optado por regestar los asientos, acompañados de un índice onomástico.
\end{abstract}

\section{PALABRAS CLAVE}

Escribano público. Registro notarial. Cuenca. Diplomática notarial. Sociedad medieval.

\section{ABSTRACT}

The publication of the present article shows the importance of notarial records in the Middle Ages and how they provide interested information about social issues of the inhabitants of whichever town. On this review, it is studied the first record elaborated by Simón Fernández de Moya who was invested with "fides publica» by the Council of Cuenca at municipal session on 7th May 1423. Two aspects can be taken into account by the diplomatist: the external and the internal characters according to the typification of Diplomatic about business. Because of the material imposibility to transcribe completely the record book, the present essay only summarize all seats as well as an index of names.

\section{KEYWORDS}

Notary public. Notarial record. Cuenca. Notarial Diplomatics. Medieval society. 
Cuando hace ya algunos años «movía papeles» en el Archivo Municipal de Cuenca para mi Tesis doctoral ${ }^{1}$ tropecé con un cuaderno que llevaba, y lleva, la siguiente nota de archivo: «Legajo 23. 1423. Leg. 23. Cuaderno de obligaciones, poderes y otros instrumentos públicos otorgados en esta ciudad, Huete y otros pueblos, y ninguno hace en favor de Cuenca. Año de 1432. Obligaciones" 2. Está escrita sobre un folio de papel de hechura claramente distinta al resto del cuaderno y que según la filigrana que porta nos lleva, como mucho, a los años treinta del siglo $\mathrm{XVI}^{3}$, testimonio de los trabajos que realizó el Concejo conquense para poner en orden sus documentos ${ }^{4}$, aunque fuera únicamente protegiendo el cuadernillo con un folio de papel. Sobre este soporte se redactó la mencionada nota, en letra bastarda con zarcillos y envolventes que se inclina a la derecha, típica del siglo XVIII, sin ninguna duda nuevo testimonio, en este caso, de la «ordenación de fondos ${ }^{5}$ que en el último cuarto del setecientos se realizó en dicho archivo.

Una vez realizado su examen vimos que se trataba del registro notarial de un escribano público de Cuenca, de los que no habíamos encontrado hasta entonces ningún otro ejemplar tan antiguo, y tampoco posteriormente. Volvemos años después sobre él porque creemos de interés su estudio, ya que es el más lejano testimonio seriado de la práctica registral de las escribanías públicas conquenses llegado hasta nosotros ${ }^{5}$. Esto no quiere decir que los notarios anteriores no llevasen cuidadosa escrituración de los negocios que autenticaban ${ }^{7}$, pues de los primeros años ochenta del siglo xIII datan las dos menciones más antiguas que conocemos de registros en tierras conquenses, que nos viene por conductos distintos. El primero nos llega

1 La documentación del Archivo Municipal de Cuenca. 1190-1417. Estudio diplornático e histórico-institucional, Madrid, 1995 (ed. en microficha de la Universidad Autónoma de Madrid).

2 Archivo Municipal de Cuenca (A.M.C.), Leg. 1503, Exp.1.

3 Esto no quiere decir que se emplease en estos años, pues es bien sabido el estocaje que se producía en las instituciones para ser utilizado cuando se necesitaba, a veces bastantes años después. El papel lleva la filigrana de la mano extendida rematada con una flor de cinco pétalos. No es el momento de entretenernos en los pequeños detalles que marcan las variantes al tipo encontrado en nuestro papel, aunque sí podemos apuntar que se extiende en una cronologia que abarca desde finales del siglo $x v$ hasta los años treinta del siguiente. Como ejemplo de lo que decimos puede verse: F. A. CHACón GómezMonedero, "Papel filigranado en el Archivo de la Catedral de Cuenca», en Actas del il Congreso Nacional de Historia del Papel en España, Cuenca, 1997, pp. 194-195, 227, nn. 29-33. J. L. BASANTA CAMpos (Coord.). Marcas de agua en documentos de los archivos de Galicia hasta 1600, Fundación Pedro Barrié de la Maza, Conde de Fenosa, 1996, vols. I-ll. G. Gayoso Carreira, Historia del papel en España, Lugo, 1994, Vol. III; "La filigrana de la mano en documentos de Galicia (España) de los siglos XVI y XVII", en Investigación y Técnica del papel, 22 (oct. 1969) 1069-1086. O. Valıs I Subirá, La Historia del papel en España. Siglos XV-XVI, II, Madrid, 1980, pp.150-158 y nn. 155, 162, 172, 179.

4 M. JimÉnEz MONTESERIN, "La vida de Cuenca en tres mil legajos", Ciudad de Cuenca. Boletín de Información Municipal, 89 (julio-agosto-septiembre, 1987) 32.

5 Ibidem, idem, pp. 34-36.

6 No son muchos los conocidos y publicados en el área castellana de época más antigua al que ahora estudiamos, según señalan: J. BONO HUERTA, «La práctica notarial del reino de Castilla en el siglo xIII. Continuidad e innovación", en Notariado público y documento privado: de los orígenes al siglo XIV. Actas del VII Congreso Internacional de Diplomática (Valencia, 1986), Valencia, 1989, p. 497; Breve introducción a la diplomática notarial española (parte 1. ${ }^{\text {) }}$. Sevilla, 1990, p.41, y en la Introducción que hace al trabajo de M. D. Rojas VACA, Un registro notarial de Jerez de la Frontera (Lope Martinez, 1392), Madrid, 1998, pp. 13-14. M. L. PARdo RodriguEZ, Señores y escribanos. El notariado andaluz entre los siglos XIV $y \times v i$, Sevilla, 2002, p. 52.

7 Tal como se indicaba en las Partidas, $3,18,55$ y $3,19,54$. 
desde el propio Concejo, cuando mandó a Pero García, escribano público, registrar la Ordenanza municipal elaborada en 14 de noviembre de 1280 y que establecia los derechos devengados por la utilización de su sello, dando a la escrituración registrada idéntico valor jurídico ${ }^{8}$. El segundo procede de la Cancillería regia en 1285 , y es Sancho IV quien en el "amejoramiento" del Fuero de Cuenca nos deja ver el valor que concedía al Registro público como instrumento de prueba a la hora de regular las relaciones prestarias entre las comunidades cristiana y judia ${ }^{9}$.

Según nos dice la nota de apertura, el viernes, siete de mayo de 1423, «la ciudad de Cuenca", haciendo uso de las prerrogativas que le otorgaba el Fuero, confirmadas por Alfonso XI en 1335 y por algunos de sus sucesores ${ }^{10}$, concedió la «fe de la ciudad" a Simón Fernández de Moya, que ya era escribano del rey ${ }^{11}$. El nombramiento se llevó a cabo en una sesión municipal ${ }^{12}$ ante la presencia de Juan López de Buenache, "escrivano de los fechos del Concejo" ${ }^{13}$, y posteriormente se le

8 «Et mandamos que esta carta que esté en el arca de los privillejos, et mandamos a Pero García escrivano de Cuenca, que la meta en el registro, et, si por aventura se perdiere esta carta, mandamos que vala el registro della tan bien commo esta carta". Cfr. F. A. Chacon Gomez-Monedero, Colección diplomática del Concejo de Cuenca. 1190-1417, Cuenca, 1998, pp. 102-103, n. 19.

9 “Otrossí, el judío, quando recibiere paga de lo quel deven los christianos, vaya ante los escribanos públicos et, sil fiziere paga de todo, del su carta, et el escribano sáquela del registro, et si de todo nol fiziere paga, aquello quel pagare escribalo entre los reglones de la carta del debdo, et el judío que contra esto fuere peche diez maravedís, la meytad a los alcaldes et la meytad al querelloso". Cfr. Ibidem, idem, pp. 111-114, n. 25.

10 Hace algunos años publiqué un articulo sobre los escribanos en la ciudad de Cuenca, donde dejé constancia de la documentación original y de abundante referencia bibliografíca sobre el tema; trabajo al que remito para no repetir, creemos que innecesariamente, lo alli expuesto. F. A. ChaCON GómEz- MoNEDERO, «El oficio de escribano en la ciudad de Cuenca. Siglos XIII-XIV», en Revista Jurídica del Notariado, 10 (abril-junio 1994) 79-118.

1: La doble competencia no era un hecho extraordinaro, antes al contrario, véase J. BONO HUERTA, Historia del Derecho Notarial Español, I.2, Madrid, 1982, p. 297, nota 5. Para todo lo referente a los escribanos de creación real y a sus competencias remitimos a las pp. 14-115, 150-152, 295-303; Breve introducción, pp. 23-24, 29.

12 Por desgracia no conservamos el comienzo del Libro de Actas donde se recogería la sesión municipal nombrando a nuestro escribano. El libro de 1423 ha perdido sus primeros folios y comienza en la sesión del 28 de mayo, mientras que el nombramiento que nos ocupa tuvo lugar el día ocho del mismo mes. Sin duda en esta sesión se nombraron más de un escribano, pues el día 28 se recoge una impugnación a los nombramientos por parte del Guarda Mayor de la ciudad: «Este dicho día, Diego Furtado dixo que por razón quel dicho Corregidor e regidores avian fecho e criado çiertos escrivanos contra la ordenança fecha entre la çibdat e los escrivanos públicos della que él, en quanto Guarda, que non consentía en la tal fechura e criaçón, e que lo contradeçía. E pidiólo por testimonio. Testigos los suso dichos", (A. M. C. Leg 187, Exp. 2, f. 1). Tampoco conservamos la ordenanza a la que apela el Guarda Mayor y que regulaba, al parecer, las condiciones pactadas que se debian observar en los nombramientos de escribanos públicos, pero no respetadas por el Concejo, según el parecer de Diego Hurtado. Quizá no estuvieran muy lejos de tal protesta los intereses de la Corona, pues también sabemos de sus enfrentamientos con el Concejo a la hora de proveer estos oficios públicos. Véase la exposición de un caso concreto en M. P. RÁBADE OBRADÓ, "Las escribanias como conflicto entre poder regio y poder concejil en la Castilla del siglo XV: el caso de Cuenca», en Anuario de Estudios Medievales, 21 (1991) 247-276.

13 Juan López de Buenache es Escribano del Concejo desde 1411, año en el que fue nombrado para dicho cargo por el infante Fernando de Antequera en las ordenanzas que promulgó ese mismo año y que introducian importantes cambios en el organigrama del gobierno municipal, entre ellas la implantación vitalicia del "Escribano del Concejo e Ayuntamiento", con un salario anual de 2.000 maravedis, pues consideraba el infante que era más beneficioso para la ciudad que los asuntos del Concejo pasasen siempre ante la misma persona "que no ante muchos". Las ordenanzas se conservan en una confirmación realizada por Juan $\|$ en septiembre de 1423, y que fueron publicadas por M. D. CABAÑAS GonzALEZ, "La re- 
recibiría el juramento de fidelidad al Rey y a la Ciudad, según estipulaba la ley ${ }^{14}$. Era éste un requisito imprescindible para ser investido en el cargo y concederle la "auctoritas" mediante el correspondiente "título» ${ }^{15}$ que expedía el Escribano del Concejo, y que le facultaba para ejercer el "officium notariae» en la ciudad de Cuenca como "publicus notarius", pues ese mismo día asienta los primeros negocios en el registro objeto del presente estudio. En concreto nada sabemos del sistema que se siguió en su elección ${ }^{16}$ y posterior investidura, pues nada se nos dice en los siguientes nombramientos realizados a primeros del mes de julio y que se nos han transmitido en la correspondiente acta municipal ${ }^{17}$.

El Registro tuvo una vigencia de cinco meses, de mayo a septiembre, en los que recoge un total de 77 asientos de otros tantos negocios jurídicos ${ }^{18}$, la mayoría actuados en la ciudad de Cuenca, aunque en el mes de septiembre nuestro escribano hace dos salidas a pueblos cercanos para atender a otros clientes y escriturar sus negocios ${ }^{19}$. Durante los días 15 y 16 deja constancia de su presencia en Huete ${ }^{20}$ re-

forma municipal de Fernando de Antequera en Cuenca", en Cuenca y su territorio en la Edad Media. Actas del I Simposio Internacional de Historia de Cuenca (Cuenca, 1977), Madrid-Barcelona, 1982, pp. 381397. Sobre la figura del Escribano de Concejo, remito a la obra ya clásica de E. CorRal Garcia, El es. cribano de concejo en la corona de Castilla (siglos xI al XVIII), Burgos, 1987.

14 Fuero Real, 1, 8, 1; Speculum, 4, 12, 2; Partidas, 3, 19, 4. Todo esto puede verse ampliamente comentado en J. BONo HuERTA, Historia, I. 2, pp. 240-253.

15 Véase Ibidem, Breve introducción, p. 28.

${ }^{16}$ Las leyes establecian que los candidatos tenían que demostrar sus conocimientos técnicos, además de sus aptitudes fisicas, estudios, religión, moralidad y vecindad, que les capacitaban para ejercer adecuadamente la profesión de escribano. Todo esto está perfectamente recogido en F. ARRIBAS ARRANZ, "Los escribanos públicos en Castilla durante el siglo XV", en Centenario de la Ley del Notariado. Estudios Históricos, Madrid, 1964, pp. 172-178. J. Bono HUERTA, Historia, 1.2, pp. 202-240. Sirvan, además, los siguientes ejemplos: L. PASCUAL MARTínEZ, «Estudios de diplomática castellana. El documento privado y público en la baja Edad Media: los escribanos", en Miscelánea Medieval Murciana, 8 (1981) 136-141. P. Ostos SALCEDO, “Los escribanos públicos de Córdoba", pp. 180-187. M. L. PARdo Rodríguez, «El notariado de Sevilla", pp. 262-273. M. VAZQUEZ BeRtomeu, Notarios, notarias y documentos en Santiago y su tierra en el siglo xv, La Coruña, 2001, pp. 25-33.

17 Como ya hemos dicho no se conserva el acta donde quedó asentado el nombramiento de Simón Fernández, aunque si la que tuvo lugar unos dias después en favor de dos nuevos escribanos, así como el juramento que realizaron y que, por pensar que seria semejante, hemos transcrito en el Apéndice.

${ }_{18}$ Descartamos el asiento del f. 21 r., pues lo creemos totalmente ajeno a la unidad de este registro que analizamos.

${ }_{19}$ Las salidas fuera de la ciudad entraban dentro de las obligaciones que contraian los escribanos en el momento de su investidura, así como las cantidades que podian percibir en estos desplazamientos. Véase este aspecto en el Apéndice.

${ }^{20}$ Como decimos, entre las obligaciones que adquirian los escribanos públicos está la de desplazarse a los lugares que el Concejo les mandaba; no obstante, la presencia de nuestro escribano en Huete nos produce algunos interrogantes, toda vez que esta ciudad disponía de escribanos públicos al menos desde 1289, según vemos en un carta abierta de Sancho IV por la que autoriza a Pedro Sánchez, su escribano, que pueda poblar el lugar de Palmiches, entregándole por vasallos a los nuevos pobladores: “...e mandamos que le vala para sienpre, así la carta commo el traslado della firmado de scrivano público de Huepte o de qualquier otro lugar de nuestro sennorio». Ctr. F. A. Chacón Gómez-MONEDERo, Colección djplomática, pp. 118-120, n. 27. Cientamente que los negocios que presencia Simón Fernández en esta ciudad están relacionados con el Rey y, por ello, podian ser autenticados por escribanos de otras poblaciones que tuviesen la auctoritas real, como así sucedía con nuestro personaje. Pero también en Huete actuaban desde la mitad del siglo anterior escribanos con esta potestad, al menos así lo vemos en los años 1345, 1346 y 1347, aunque es verdad que siempre se trata del mismo: "Yo, Simón Fernández de Cuenca, scrivano público por mío sennor el Rey en Huepte". Ctr. Ibidem, idem, p.182, n. 64, pp. 187-187, 
gistrando cinco negocios ${ }^{21}$, y vuelve a salir de Cuenca el día 22, en esta ocasión a Fuentes ${ }^{22}$, donde en una única jornada estuvo presente en la declaración de voluntades de otros cinco clientes.

No parece tener días determinados para atender su oficina, ya que hay asientos de negocios realizados en cualquier día de la semana, excepto los domingos; por otra parte tampoco parece tener demasiado trabajo, pues lo normal es atender a un solo cliente por dia, puede haber días de dos, de tres, de cuatro y hasta de cinco, aunque, a decir verdad, esto es extraordinario y únicamente lo hemos visto en dos ocasiones, el viernes 16 de julio, y el 22 de septiembre cuando se desplazó a Fuentes. Siguiendo con la estadística, podemos añadir que el mes más laborioso fue junio, con 28 inscripciones en diez días de trabajo, a una media de casi tres actuaciones por jornada.

\section{CARACTERES EXTERNOS}

En la actualidad lo que se conserva en el Archivo Municipal de Cuenca ${ }^{23}$ es un cuaderno de papel formado por 21 folios de $300 \times 215 \mathrm{~mm}$., fabricados en el mis-

n. 67, pp. 190-191, n 70. Creíamos haber encontrado una solución a esta presencia a la luz de la información que nos proporciona el profesor Sánchez Benito cuando habla de que «los escribanos del número que ejercian en la ciudad eran designados generalmente por el Concejo, de acuerdo con el privilegio que tenía expresamente para ello. Bien es verdad que mientras Huete fue senorio, a fines del siglo XIV y principios del $x v$, esta facultad pasó a manos de la Señora de la ciudad, y también que en 1439, concluida aquella situación, Pedro de Acuña recibía del Rey, por merced, tanto las escribanias como la martiniega" (J. M. SÁNCHEZ BENITO, "El poder en una pequeña ciudad castellana: el ejemplo de Huete en el siglo XV", en En la España Medieval, 25 (2002) 207). Está claro que las escrituras del Registro que analizamos se produjeron, precisamente, durante el periodo del señorío aludido, y habiamos pensado que, quizá debido a esta situación, ningún escribano había conseguido la auctoritas regia en la ciudad de Huete, siendo requerido por ello nuestro escribano que, como sabemos, gozaba de ambas jurisdicciones; pero no podemos alegar esta circunstancia, toda vez que en cuatro de los cinco negocios escriturados en Huete aparece como testigo un tal “Gutierre González de Guadalfajara, escrivano del rey", (nn. 67, 69, 70 y 71 ), lo que invalida nuestra hipótesis y nos deja, por el momento, sin explicación convincente. Tengamos en cuenta, también, que según la legislación castellana (Especulum, 4, 12, 3 y Partidas, 3, 19, 2), los escribanos debian ser vecinos del lugar donde ejercían su oficio. Cfr. J. Bono Huerta, Historia, I. 2, pp. 219-220.

21 nn. $67,68,69,70$ y 71 .

${ }^{22} \mathrm{nn} .73,74,75,76$ y 77 . El desplazamiento a Fuentes creemos que está perfectamente justificado, ya que se trata de una pequeña aldea perteneciente a la Tierra de Cuenca y no nos consta que tuviera capacidad para nombrar a escribanos públicos, ni que en ella residiera ninguno con auctoritas regia.

${ }^{23}$ No es extraño que los pocos registros de escribanos públicos de época medieval que se han estudiado se encuentren entre los fondos de archivos municipales, como es el caso que nos ocupa, pues aunque el officium tenía carácter patrimonial, a la muerte de un escribano público era obligada la presentación de sus "papeles» ante el Escribano del Concejo, o la autoridad municipal se hacia cargo de ellos, quien los custodiaba hasta la entrega a su sucesor en el "oficio", lo que sin duda ocasionaba algún que otro olvido, y de ahí la presencia de los registros en estas instituciones locales. Véase la información que dan al respecto: J. BONO HUERTA, Los archivos notariales, Sevilla, 1985, pp.11-13. A. CANELLAS LóPEZ, "El notariado en España hasta el siglo xIV: Estado de la cuestión", en Notariado público y documento privado: De los orígenes al siglo xIv. Actas del VII Congreso Internacional de Diplomática (Valencia, 1986), Valencia, 1989, p.125. M. L. PARdo Rodriguez, Señores y escribanos, pp. 67-71. La doctrina sobre la recogida y custodia de los registros desde la muerte del titular hasta la entrega al sucesor (Partidas, 3, 18, 55) está compendiada por A. Rodriguez Adrados, "La Pragmática de Alcalá, entre las Partidas y la Ley del Notariado", en Homenaje a Juan Berchmans Vallet de Goytisolo, VII, Madrid, 1988, pp. 745-749. 
mo molino, pues así lo certifica la única filigrana de «los tres montes» que se repite en cada uno de sus pliegos, y que probablemte proceda de Italia ${ }^{24}$. La caja de escritura es bastante regular, con márgenes que no suelen superar los $15 \mathrm{~mm}$. en cabeza y los $30 \mathrm{~mm}$. en pie y a la izquierda, mientras que el margen derecho es siempre mucho más irregular y estrecho. Los folios se cubrieron hasta el $20 \mathrm{r}$, el verso está en blanco, en torno a 35/37 renglones tendidos, la mayoría escritos por la misma mano e idéntica a la que puso la notación de apertura o título. Nos parece que en otros asientos ${ }^{25}$ ha intervenido una segunda mano, que realiza una letra de ductos más rápido y trazado más redondeado y ancho, en la que observamos un mayor hábito a la hora de curvar los caídos hacia la izquierda apenas han rebasado la línea de renglón, con un sistema de ligaduras y nexos más desarrollado. Quizá se trate de la mano de Simón Fernández, pues suele coincidir con su presencia al final del elenco de testigos, que cierra con un signo más complicado que el de simple clave de sol que es el habitual en la clausura de la inmensa mayoría de los asientos. Aunque ambas manos usan preferentemente la «s sigmática" al final de palabra y la "a de lineta» se abra paso lenta, pero decididamente, creemos que, en conjunto, las grafías utilizadas aún se deben englobar en el arco de las escrituras denominadas "precortesanas» ${ }^{26}$.

Todo nos hace pensar que estuvo formado por un sólo fascículo de 12 bifolios, originariamente cosidos con un bramante fino por el doblez en tres grandes puntadas, aunque en la actualidad contamos, como ya dijimos, con 21 folios, faltándole los tres últimos, que propició el que sus solidarios se desprendieran del fascículo. Idéntica suerte han corrido algunos otros folios que debido al uso se han cortado por el doblez, teniendo que ser de nuevo todos cosidos con hilo blanco de forma no muy convencional. Originariamente no estuvo foliado, aunque ahora tenga una numeración contemporánea, arábiga y a lápiz, sobre el ángulo superior derecho ${ }^{27}$. Como según Bono Huerta ${ }^{28}$ era costumbre en la Castilla del siglo $\mathrm{XV}$, nuestro escribano custodiaría estos folios dentro de un simple cartapacio, pues no imaginamos otro tipo de protección, ni tan siquiera alguna sencilla cubierta de pergamino.

El último asiento es el de 22 de septiembre, en desacuerdo con la intención primera del escribano, manifestada en la diligencia de apertura, que le concedía la vigencia del año en curso ${ }^{29}$, es decir, hasta diciembre de 1423 . Por alguna razón que ignoramos se dejó de utilizar de forma voluntaria ya que aún le quedaban, al

${ }^{24}$ Ch. Briquet, Les filigranes. Dictionnaire historique des marques du papier, Leipzig, 1923, III, p. 588. Papel con esta misma filigrana ya utilizaba el cabildo a finales del siglo xv. Véase, F. A. CHACón GómezMONEDERO, “Papel filigranado", pp. 195 y 227, n. 30. Para no alargarnos repitiendo la bibliografia ya citada, véase la nota 3.

$25 \mathrm{nn} .11,31,32,35,43,71$.

26 A. Millares Carlo, Tratado de Paleografía Española, I, Madrid; 1983, p. 225. M. J. Sanz Fuentes, "Paleografía de la Baja Edad Media castellana", en Anuario de Estudios Medievales, 21 (1991) 527-536.

27 Erróneamente se comenzó la numeración en el folio que hace de portadilla.

28 Breve introducción, p. 41.

29 Adaptándose al periodo de tiempo que ya se había impuesto como normal para contener las escrituras protocolizadas, y hacer estos instrumentos operativos en las "escribanias". J. Bono HUERTA, Breve introducción, p. 39. 
menos, folio y medio por cubrir ${ }^{30}$ de los conservados hasta hoy, lo que nos indica que no han desaparecido otros asientos violentamente.

No parece que nuestro escribano fuera un perfecto conocedor de la legislación alfonsi ${ }^{31}$, a la vista de como realiza algunas de las tareas que conlleva la conscriptio de los negocios que fedata, o simplemente la ignora, algo que parece ser habitual en el comportamiento de los escribanos ${ }^{32}$. En concreto, y en contrario a lo dispuesto por la ley, encontramos, regularmente, la utilización de siglas para escribir los nombres de los que intervienen en cualquier fase de la actio documental, asi como el empleo de números romanos para señalar las fechas de los negocios y de algunas cantidades monetarias. Tampoco hemos encontrado "salvedad de tachas" cuando se ha producido algún tipo de intervención en el texto de las notas, lo que es normal, pues hay frases y palabras tachadas ${ }^{33}$, entre líneas ${ }^{34}$ y espacios en blanco ${ }^{35}$. Del mismo modo, y aunque no sea frecuente, se han etceterado los cargos de personajes ciudadanos cuando han aparecido en un asiento previo, así como algunas cláusulas renunciativas ${ }^{36}$, palabras "técnicas" repetidas y frases que hoy podrímos considerar como «hechas».

${ }^{30}$ Se encuentra en blanco el f. $20 \mathrm{v}$. y el 21. El recto del f. 21 se utilizó posteriormente para escriturar una "petición de licencia", que quedó inconclusa, y a todas luces fuera de la vigencia de nuestro registro, pues data de los años cincuenta, sin que sepamos cual fue el motivo de su inclusión aquí, además de actuarse ante otro notario público, Lope González de León. Hemos añadido su regesto, pero no lo hemos tenido en cuenta en el análisis diplomático ni en el índice.

31 Recogida perfectamente por J. BONO HUERTA, Breve introducción, p. 42, que nos excusa de su repetición.

32 Véase A. Rodriguez Adrados, "La Pragmática", p. 725, quien llega a calificar a las Partidas como "un paradigma de normas secularmente incumplidas".

${ }^{33}$ Son muchos los asientos en los que se observa esta circunstancia, por lo que omitimos su relación pormenorizada. No son sino equivocaciones sin importancia del amanuense. Véase, A. RodrigueAz ADRADOS, «El registro notarial de Madrid (1441-1445). Estudio documental», Los registros notariales de Madrid. 1441-1445, Madrid, 1995, p.191

$34 \mathrm{nn} .2,4,7,20,29,30,34,43,47,48,51,64$. Cuando hay palabras o frases entre líneas normalmente se ha señalado el lugar exacto de su ubicación mediante dos pequeñas rayitas oblicuas sentadas sobre el renglón.

${ }^{35}$ n. 5 . Se ha dejado en blanco el nombre de uno de los actuantes, mientras que en el n. 12 falta por concretar el cereal que llenaba una saca, y en el $n$. 54 completar cierta cantidad de maravedís. Junto a estos blancos, que no consideramos de importancia, encontramos otros dos ( $\mathrm{nn}$. 10 y 59 ) que sí pudieran tenerla en orden a darnos algunos indicios sobre el momento en que se asentaron en el Registro. Se trata de dos grandes espacios dejados en blanco por motivos distintos, pero en ambos casos porque la conscriptio se realizó con posterioridad a la actio. El n. 10 es un negocio, aparentemente completo, donde el espacio se ha dejado entre el final del negocio y la nominación de testigos, y parece que de forma calculada para insertar algún otro documento, quizá alguna especie de inventario, pues de una carta de dote se trata. El n. 59 se interrumpe bruscamente al segundo renglón, una vez iniciado lo que parece un expositivo; después del espacio se encuentra la indicación de los testigos. En este caso en el centro del blanco se ha realizado un signo agrandado de los que cierran algunos asientos y que hemos sugerido que pudieran estar trazados por la mano del propio escribano, lo que nos parece más verosímil a la vista del presente, que puede tener el significado de evitar ulteriores interpolaciones en esta nota que se proyectó pero no llegó a completarse, quizá porque una rápida expedición de la carta lo hiciera innecesario, tal como nos parece indicar la notación que sigue a la nómina testiúm: "Está fecho este racabdo en nota e es sacado signado". Sobre la interpretación de los blancos para determinar el tiempo en que se escribian las notas nos ha servido la experiencia sacada por A. RodRíGUez AdRADOS, "El registro notarial», pp. 188-191; sobre la legislación acerca de los tiempos de la redacción de la nota véanse las pp. 194-198.

${ }^{36} \mathrm{nn} .25$ y 45 . Sobre todo: «amos / a dos / de mancumún, e cada uno por el todo, renunciando a la ley de duobus rex debendi, etcétera". 
Por otra parte, a lo largo del Registro encontramos consignadas distintas anotaciones $^{37}$ :

Unas las podemos considerar «aclaratorias" y aparecen como epígrafes calificativos del negocio que se escritura: carta de censo, poder, almoneda, pregón, obligación, requerimiento, juramento, etc. ${ }^{38}$. Únicamente en una ocasión hemos visto una de estas notas consignada en el margen izquierdo, «pregón» ${ }^{39}$, donde también se han situado las aclaraciones del orden de la publicación de otro de los pregones: «primero», "segundo», «tercero" ${ }^{40}$, aunque este particular también se ha indicado al final del tenor de los asientos respectivos y entre líneas oblicuas: «/Este es el primero (segundo) (terçero) pregón/» ${ }^{41}$.

Hay otras, las más numerosas, que inciden en el otorgamiento, modificándolo o extinguiéndolo, que han sido añadidas con posterioridad y por diferentes motivos. En su gran mayoría son de las consideradas como "cancelatorias". De estas características encontramos las que anulan documentos de deuda: unas indican escuetamente haberse satisfecho la deuda que originó el documento ${ }^{42}$; mientras que en otras ocasiones son verdaderas diligencias al presentarse acompañadas de su propia nomina testium y data ${ }^{43}$. A estas notaciones gráficas se añade la visualización de la impronta de las consabidas barras cruzadas cancelatorias, una ${ }^{44} \mathrm{o}$ tres $^{45}$. También encontramos otro asiento ${ }^{46}$ clausurado con un aspa, donde se ha puesto, además, una nota de nulidad con la palabra latina «Nihil» en el centro del renglón y separado del tenor, una vez hecha la manifestación de testigos ${ }^{47}$.

37 Seguimos la terminología propuesta por J. BOno HuERTA, Breve introducción, pp. 43-44; Los Archivos Notariales, pp. 25-28. Puede verse también, P. Ostos SALCEDo, “Diplomática notarial en la época colombina: fases de redacción y forma documental», en Tra Siviglia e Genova: Notaio, Documento e commercio nell étà colombiana, Milano, 1994, pp. 200-204; “Los escribanos públicos de Córdoba en el tránsito de la Edad Media a la Moderna. Una aproximación", en El Notariado Andaluz en el tránsito de la Edad Media a la Moderna, Sevilla, 1996, 206-209.

38 nn. $4,9,14,15,17,18,19,20,22,23,25,27,28,40,61,73$.

39 ก. 30 .

$40 \mathrm{nn} .14,15,18$.

4 nn. 14, 15 y $18 ; 22$ y 30.

42 ก. 17. "Testose porque pagó".

43 n. 38. "E mandado testar por amas las partes. En XX VI días del dicho, los dichos Martin Enrríquez e Juan Ferrández, mandaron testar este recabdo , porque se cunplió por amas las partes . Testigos,...". El n. 45 se canceló casi un año despues de haberse otorgado: "En VI dias de mayo, anno de XX IIII, el dicho Ferrand Sánchez mandó testar este recabdo por quanto dixo que era pagado del debdo en él contenido. Testigos, ...". M. A. MOREnO TRuJILlo, “Diplomática notarial en Granada en los inicios de la modernidad (1505-1520)", en El notariado andaluz en el tránsito de la Edad Media a la Edad Moderna, Sevilla, 1995, p. 96, denomina a estas diligencias de "escrituras posteriores". La diferencia con las de nuestro registro es únicamente de situación, pues aquí las encontramos al final del tenor, mientras que Moreno Trujillo las sitúa como «notas marginales". Véase la opinión matizada a la denominación de "escrituras posteriores" que expresa J. Bono Huerta en la Introducción (p. 17) a la obra donde se recoge el articulo citado.

44 n. 38.

$45 \mathrm{nn} .17,45$.

46 n. 5. Es el asiento de la anulación de un arbitraje, en el que ha quedado en blanco el nombre de la parte "defendiente".

${ }_{47}$ M. A. Moreno TrujIllo, «Diplomática notarial en Granada», p. 96, denomina a estas notas «de revisión o expedición". 
Las indicaciones de que algunos negocios completaron su iter y se ha expedido el documento partiendo del texto registrado ${ }^{48}$, las encontramos con doble manifestación que no se excluyen, sino que aparecen juntas. Por un lado según la práctica habitual en Castilla que se expresa con la figura de dos «ff», muy cursivas y descendentes, situada en la parte superior del margen izquierdo y que corresponden a «fecha»; pero mezclada con los largos y anchos descendentes de esta figura encontramos, en la mayoría de los casos, la abreviatura $" \mathrm{~s}^{a}$ ", donde la sigla es una ancha "s sigmática «, y cuyo desarrollo pensamos que corresponde a "sacada» ${ }^{49}$. En un asiento ${ }^{50}$, además de estas marcas externas, encontramos una explícita mención a la "extensión documental» que venimos comentando, pues se trataría de la manifestación del triple ${ }^{51}$ proceso realizado por el notario en la conscriptio documental y que quedaba reflejado en diferentes instrumentos, la nota, el registro y la redacción definitiva, dice así: «Está fecho este recabdo en nota e es sacado signado".

Por último las hay que parecen haberse realizado para servir de información al escribano ${ }^{52}$ o como testimonio de haber cumplido un mandato judicial ${ }^{53}$. Digamos, también, que al contrario de lo que es usual en Castilla ${ }^{54}$, la única vez que se hace alusión a un documento complementario, en este caso una carta de poder, se ha copiado integro en el tenor de la nota ${ }^{55}$.

\section{CARACTERES INTERNOS}

\section{Del Registro}

Como ya hemos dejado constancia de ello, se inicia con una amplia notación de apertura donde se explicita la calidad jurídica del instrumento notarial, autocalificado de «Registro» ${ }^{56}$, seguido de la intitulación completa del auctor, en la que no

48 Según la disposición del Fuero Real, 1, 8, 3, y las Partidas, 3, 18, 54.

49 nn. $6,13,23,25,31,32,33,35,36,37,44,49,55,56,58,59,62,64,66,67,68,69,70,71,72$.

${ }^{50}$ ก. 59.

51 Véase la nota 56.

52 n. 35. "Hay otro registro deste contrato", situado en el espacio que queda a la izquierda del epigrafe; n. 72. "Hay otro registro más largo", después de la comparecencia de los testigos. Ambos casos nos hacen pensar en otro clibro" que pudiera llevar el escribano para negocios concretos, aunque los mencionados no sean del mismo tipo negocial, o bien que se trate del "libro de notas", donde se tomaron los primeros datos para la extensión posterior, lo que no coincide con la apreciación de que el otro es "más largo".

$53 \mathrm{nn} .20,22$. "Asentóse en el mandamiento", al final del tenor y entre lineas oblicuas. Ciertamente son dos documentos que se han elaborado por order judicial.

54 J. BONo Huerta, Los Archivos notariales, p. 28.

55 n. 4. También se sigue esta misma práctica en el registro que estudia M. D. Rojas VACA, un registro notarial, p. 53.

${ }^{56}$ Como es bien sabido, la práctica documental de los notarios castellanos según la legislación alfonsí de las Partidas $(3,19,9)$ se vertebraba en dos extensiones básicas, la "nota", que será posteriormente asentada en un "registro", y la "carta" o documento definitivo. Estas distintas "fases" están perfectamente expuestas y analizadas en los siguientes trabajos de J. BONo HUERTA, Historia del Derecho notarial 
se dejan de mencionar las autoridades que avalan su "oficio", tanto en el ámbíto de la jurisdicción regia, como en el más concreto del Concejo conquense, sin olvidar la fecha de su nombramiento, que será la del comienzo del Registro, y el alcance de su duración.

"Registro de Simón Fernández de Moya, escrivano del rey e escrivano público de la çibdad de Cuenca, de que la Çibdad me fizo merçed, viernes, a siete días de mayo, anno de mill e quatroçientos e veynte e tres annos. Lo qual pasó ante Juan López de Buenache, escrivano público en la dicha çibdad e escrivano de los fechos del Concejo. E los contratos e obligaçiones e cartas e recabdos e otras escripturas que por ante mí pasaron, desde el dicho día, son los que aquí dirá, e las personas que se siguen fasta en fin del mes de dizienbre del dicho anno".

A continuación se asientan cronológicamente las distintas notas que, con algunas sencillas variantes, siguen el mismo curso durante todo el periodo vigente:

Se encabezan en posición central por epigrafes que resumen el contenido, trazados por la misma mano del tenor, y separados del texto por pequeños espacios en blanco. Los datos que aportan no son en absoluto homogéneos, pues aunque siempre indican el objeto del negocio jurídico, y en una buena proporción únicamente con la escueta mención del término que lo califica ${ }^{57}$, los hay que, además, aportan alguna otra información sobre el tema actuado; por ejemplo: «Recabdo sobre la fialdad de las salinas de Monteagudo deste anno" ${ }^{58}$. Después, no son pocos los que junto a la calificación del negocio, añaden la identificación de la parte o partes actuantes, en los bilaterales: nombres y apellidos, vecindad, y no es infrecuente encontrar la mención al oficio.

El epígrafe del asiento que inicia jornada incorpora la fecha que servirá de referencia a todos los inscritos en el mismo día ${ }^{59}$, bajo las locuciones de "Este día», cuando es el primer asiento de la jornada, y "Este dicho día», para los subsiguientes ${ }^{60}$. No es frecuente la indicación del dia de la semana ${ }^{61}$, pero siempre

español, 1. 1, Madrid, 1979, pp. 238-255; Breve introducción, pp. 32-44, a los que remitimos para evitar repeticiones de algo ya bien sabido. Puede verse del mismo autor, "La práctica notarial, p. 499-500; «Modos textuales de transmisión del documento", en Estudis Historics i documents del Arxius de Protocols, XIII, Barcelona, 1995, pp. 75-85, y también M. VÁzquez BerTomeu, Notarios, notarías, pp. 39- 42, donde recoge abundante bibliografía al respecto. El documento que analizamos es, pues, un "Registro", y no sólo porque como tal se autocalifica, sino también porque formalmente es una "colección continua, ordenada cronológicamente, de las notas formalizadas en un periodo de tiempo por un determinado notario, en la forma orgánica de libro, integrado por cuadernos", y comprendiendo un periodo temporal predeterminado, que también aparece señalado en el epigrafe intitulativo; además de carecer de cualquier clase de suscripciones, tanto de otorgantes como de los testigos y escribanos, coincidente con lo señalado por J. BoNo HUERTA, "Una aportación especializada: el registro de Dueñas y la práctica notarial del reino de Castilla", p. 61, en R. Pérez-Bustamante, El Registro notarial de Dueñas, Palencia, 1985.

57 Propiamente serian "notaciones aclaratorias", según las denomina J. BONO HUERTA, Breve introducción, p. 43.

58 n. 1 ; también nn. $34,47,49,69$.

59 Hay una excepción a esta práctica en el $n$. 55, pues siendo el segundo asiento vuelve a repetir los mismos elementos de dia y mes.

60 Véase J. Bono Huerta, Breve introducción, p. 36.

61 $\mathrm{nn} .5,16,21,24,26,29,32,36,38$ y 48 . 
menciona el día del mes ${ }^{62}$ y su nombre ${ }^{63}$, y el año en decenas y unidades, aunque en ocho ocasiones ${ }^{64}$, sin que hayamos encontrado ningún denominador común para ello, el año se refleja completo, todo en numeración romana cursiva y las unidades de millar con «|» seguido del "calderón» que lo multiplica por mil ${ }^{65}$.

Ya hemos dicho que algunos dias del mes de septiembre nuestro escribano estuvo fuera de Cuenca para atender a clientes de dos pueblos cercanos a la ciudad y presenciar sus negocios que, posiblemente, recogería en algún cuaderno de notas o en apuntes sueltos para extenderlas en su Registro una vez de vuelta en su oficina conquense ${ }^{66}$. En estas ocasiones las datas que aparecen en los epígrafes de las primeras escrituras se inician con la mención del topónimo, «En Huete...» ${ }^{67}$, «En Fuentes...»68. De regreso a la ciudad, donde va a escriturar ya únicamente dos negocios ${ }^{69}$, lo indica dejando constancia de ello en el centro del renglón, separado del resumen, "En Cuenca».

Conviene señalar la irregularidad que supone la ubicación fuera de lugar de una nota que por su orden normal le correspondería, ya que datada el día 31 de agosto $^{70}$, se encuentra asentada después de la primera del mes de septiembre ${ }^{71}$. No podemos dejar de mencionar el que la gran mayoría de estos epígrafes estén abiertos por signos de párrafo $(\rho)$ de los llamados cursivos por Floriano ${ }^{72}$, con la particularidad de que si la data está en renglón aparte, lo que sucede con frecuencia, se precede de igual forma. Para cerrarlos se ha utilizado el signo parecido a una clave de sol, aunque también nos podemos encontrar con una o dos líneas oblicuas seguidas de tres puntos ${ }^{73}$.

\section{De los asientos}

Pasamos ahora a comentar la estructura interna de los tipos documentales escriturados en nuestro Registro. Dejarnos constancia de que se suelen abrir con sig-

62 En la única ocasión en que la fecha ha coincidido con el comienzo de un nuevo mes ( $\mathrm{n}$. 46) lo ha señalado con la mención usual en Castilla de "en primero dia de...".

63 Normalmente, en los epígrafes del mismo mes su nombre se antecede de la locución «...de dicho mes de ..."

$64 \mathrm{nn} .10,26,34,49,51,60,65$ y 67.

65 Según A. Millares Carlo, Tratado, I, p. 275, es un signo que se fue imponiendo hasta desbancar prácticamente a la M durante el siglo XvI.

${ }^{66} \mathrm{~J}$. Bono Huerta, "Una aportación especializada", p. 64. R. PÉrez-Bustamante, Los registros notariales de Madrid 1441-1445, p.199.

${ }_{67}$ ก. 67. Se refleja la data completa: «En Huete, a quince dias de setienbre, anno de IU CCCC XXIII»

68 n. 74. En esta ocasión la data está referida al "...dicho mes de setienbre».

$69 \mathrm{nn} .72$ y 73 .

70 ก. 66.

71 n. 65. Puede deberse a que se le traspapeló la nota de agosto, que encontró después de empezar a asentar las de septiembre, quizá porque la dejó sin asentar antes de emprender viaje a los pueblos mencionados.

72 A. Floriano Cumbreño, Curso general de Paleografía y Paleografía y Diplomática españolas, Oviedo, 1946, pp. 133-134.

${ }^{73}$ Quizá las siguientes figuras nos podrían dar una idea válida, $/: \cdot(/ /:)$ 
nos de párrafo, idénticos a los ya mencionados, mientras que se cierran con el de clave de sol, y en menos ocasiones con un signo más complicado gráficamente que quizá esté realizado por el propio auctor del Registro. Añadamos que la relación de testigos se hace en renglón aparte y se cierra con uno de los dos signos mencionados.

Casi todos los documentos inscritos son de derecho privado, es decir su redacción obedece única y exclusivamente a la libre voluntad de los sujetos que se han personado en la oficina notarial, o han requerido los servicios de este «funcionario público" fuera de ella, para que con su presencia cualificada legalice el negocio que han querido realizar. El resto de lo escriturado tiene su origen en la voluntad de una autoridad competente en el ejercicio de su función judicial, unas veces como conclusión de su actuación y otras como partes integrantes de un proceso de las que se quiere dejar constancia fidedigna, para lo cual se ha de recurrir igualmente a la cualificación del escribano público.

Hay tambien una mayoría de asientos redactados en forma subjetiva, mediante la cual nuestro escribano ha formalizado los documentos de contenido negocial. En una considerable menor proporción ha empleado la redacción objetiva y siempre como narración de un hecho del que se quiere dejar fidedigno testimonio de su realización.

Encontramos algunas diferencias en la estructura de los documentos según se hayan redactado en una $u$ otra forma. Es un hecho que todos los asientos se inician con la data y, mayoritariamente, referenciada al epígrafe que los encabezan, siendo aquí donde encontramos la primera diferencia entre ambas redacciones, como veremos a continuación. Las otras diferencias se encuentran en el protagonismo que asume el escribano narrando los hechos en tercera persona, quien previamente ha dejado constancia de su presencia bajo fórmulas precisas que así lo aseveran ${ }^{74}$, para continuar con la comparecencia de los autores.

No obstante, la estructura diplomática del conjunto documental escriturado presenta las suficientes similitudes como para realizar su análisis de forma conjunta, incidiendo particularmente en aquellos casos que lo requieran sus fórmulas y cláusulas ${ }^{75}$.

Como venimos diciendo, todos se inician indefectiblemente por la data ${ }^{76}$, que es siempre una referencia al brevete que abre la jornada de trabajo, aunque hemos de hacer algunas salvedades:

74 Normalmente: “en presençia de mí; "ante mi». Ver M. D. RoJas Vaca, Un protocolo, p. 93.

75 El espacio nos impide realizar el análisis individual de cada uno de los tipos diplomáticos que se asientan en nuestro registro; con todo creemos que las semejanzas con los recogidos en otros registros publicados y que hemos consultado son evidentes. Podría servir como referencia, por ser uno de los más antiguos que se conservan, a la vez que el último publicado, al menos que yo conozca, el estudiado por M. D. Rojas Vaca, Un Registro notarial, pp. 54- 99.

${ }_{76}$ M. VÁzouez Bertomeu, Notarios, notarías, p. 59, señala la influencia que para estos comienzos pudo tener la legislación alfonsi y los tratados notariales boloñeses. 
En los tipo Acta, según requiere su redacción objetiva, al elemento cronológico completo, día de la semana, del mes y el año según el sistema de la Natividad, todo literalmente expresado, se añade el topónimo con el lugar exacto de la ciudad donde se desarrolla la actio ${ }^{77}$. Dentro de este modelo encontramos algunas variantes que simplifican su formulación: se puede referenciar el elemento cronológico al epígrafe ${ }^{78}$, mientras que en los "pregones", de los cuales tenemos dos bloques diferentes, en el primero ${ }^{79}$, que se desarrolla a lo largo de tres jornadas, sus datas ven reducidas la información cronológica con respecto al que inicia el trío; así en el que abre la serie se dan los elementos completos de día de la semana, día del mes y el año, aunque referenciado al registro en el que se inscriben; en el segundo la información es únicamente al día "del dicho mes", mientras que en el tercero se vuelve a indicar el día de la semana y del mes ${ }^{80}$. El segundo bloque ${ }^{81}$ consta únicamente de dos ${ }^{82}$ actuaciones del pregonero y en ambas se referencia la data al epígrafe.

Por otra parte, en los negocios fedatados fuera de Cuenca, el elemento cronológico es referenciado, aunque en un consciente motivo profesional señala claramente el topónimo donde ha desarrollado su trabajo, fuera de su espacio habitual de actución: "Este dicho día, en el dicho lugar Huepte/Fuentes» 83 .

En todos los asientos, inmediatamente después, se da paso a la intitulación, que consta de los datos esenciales para identificar al autor documental: nombre y apellido, con frecuencia acompañado del topónimo de procedencia, y se puede añadir el oficio o cargo y la vecindad, así como la filiación, sobre todo si se trata de menores de edad o de mujeres ${ }^{84}$, las cuales hacen constar, además, que tienen la autorización precisa para ello, del padre o del marido, con fórmulas como, "con suplicación de...» ${ }^{85}$. No es raro que se preceda de alguna locución que deja constancia de la presencia del autor o autores ante el notario, tales como "paresçió/eron y presente/es", "paresçió en persona".

Cuando se trata de negocios contractuales la intitulación es doble y normalmente sigue a la locución que constata la presencia de los autores en la oficina notarial. De la misma forma se hace constar la presencia de los autores que se obligan in solidum para responder ante un tercero, pero en estas ocasiones a los datos de los nombres sigue la cláusula de compromiso «amos / a dos / de man-

77 ก. 2.

78 ก. 42.

$79 \mathrm{nn} .14,15,18$.

${ }^{80}$ Los dias del mes se marcan en numeración romana.

$81 \mathrm{nn} .22,30$.

82 Quizá por alguna causa desconocida se interrumpió el proceso judicial que les habia dado origen y se omitió el tercer reglamentado pregón.

в3 $\mathrm{nn} .67,68,69,70,71,73,74,75,76$ y 77 .

84 Teresa de Luna no hace constar ninguno de estos pormenores (n. 39).

85 n. 63. Puede verse a este respecto un comentario sobre lo legislado en el Fuero de Cuenca en $\mathrm{S}$. Claramunt Rodriguez, "La mujer en el Fuero de Cuenca", en Cuenca y su territorio en la Edad Media. Actas del I Simposio Internacional de Historia de Cuenca (Cuenca, 1977), Madrid-Barcelona, 1982, pp. 133-147. 
cumún, e cada uno por el todo, renunciando a la ley de duobus rex debendi, etcétera» ${ }^{86}$. También se deja explícita mención de las actuaciones delegadas con los datos esenciales del poderdante. Despues podemos encontrar otras locuciones introductorias que tienen que ver, de igual modo, con el negocio: asi en una carta de soldada se antecede el nombre de "entró a soldada..." ${ }^{87}$; y en una sentencia ${ }^{88}$ de la expresa manifestación de hallarse delante de la autoridad competente, "ante...", de quien se dan los datos necesarios, sus títulos y cargos, y la autoridad superior en cuyo nombre los ejerce, además de dejar constancia de que está ejerciendo su función "a la audiençia de los viernes" ${ }^{89}$.

A esta norma general hemos de hacer constar la excepción que se observa en el negocio redactado según la clásica tipología de Acta $^{90}$, ya que antes de la manifestación de la intitulación, en este caso colegiada al tratarse de varios miembros de una comunidad religiosa, en cuyo nombre actúan, el escribano que dará fe del hecho para el que se le ha requerido, hace expresa manifestación de su presencia y de los testigos que contemplarán el desarrollo del acto, «en presençia de mi..., e de los testigos yuso escriptos". Después indicará los nombres de los miembros de la comunidad precedidos de su categoria, "maestro», "fray", y seguidos de los títulos académicos que casi todos tienen, "maestro en Teología", "doctor", "maestro de Lógica", sin dejar de hacer constar su delegación, "en nombre de los otros frayles".

Cuando en nuestros negocios se ha dado lo que en Diplomática conocemos como expositivo, es decir, la narración de los motivos concretos que justifican el hecho escriturado, lo encontramos inmediatamente después de la parte intitulativa, y en una buena proporción en relación al total de nuestros asientos ${ }^{91}$. Es de variado contenido, como lo son los documentos en que aparece, y de breve extensión, excepto en los testimonios notariales ${ }^{92}$ y la sentencia ${ }^{93}$. Se suelen referir a situaciones que han ocurrido con anterioridad al momento de poner por escrito el negocio, para que se tengan los suficientes conocimientos, próximos y remotos, de los hechos que se van a escriturar. Con frecuencia es aquí donde se da la información relativa a los destinatarios del negocio, en una especie de dirección subsumida, así como de otras personas que intervienen más o menos directamente en el desarrollo de su actio.

Como es natural, la parte dispositiva es la que nos proporciona una mayor variedad de fórmulas jurídicas, en relación a lo variados que son los negocios feda-

86 nn. 25,45 .

87 n. 60 .

88 ก. 48.

89 FUERO de Cuenca, edición crítica con introducción, notas y apéndice por R. UREÑA Y SMENJAUD, Madrid, 1935, pp. 558 y 560, cap. XXIV, I: «De appellantibus a curia alcaldum ad diem veneris»; VI: "Quid in diem veneris in curia alcaldum debeat tractari".

90 n. 2.

${ }^{91}$ nn. $2,8,11,16,20,29,34,38,41,42,47,48,49,50,51,53,57,65,67,70,72$ y 75.

92 nn. $2,42$.

93 ก. 48 . 
tados por Simón Fernández en el tiempo del que tenemos noticia de su actuación profesional. Sigue a la exposición de motivos, cuando los hay, y en general mediante las partículas "por ende", "e esto, en commo pasó...". Cuando se accede directamente desde la intitulación, es normal que se abra con el verbo o verbos que nos darán a conocer la voluntad del autor, o de los autores, en ocasiones de manera reiterativa y tautológica, como parte sustancial que es para la existencia del documento.

Es normal que al verbo ejecutivo le siga el sustantivo que determina, con la precisión requerida, el contenido y la razón de haberse escriturado el negocio jurídico concreto. Además, y según sea el contenido, se especificarán con total precisión todos y cada uno de los pormenores que lo condicionan. También podemos encontrar que se ha elegido este momento del tenor para dejar constancia de la dirección, y de forma subsumida, como la veíamos aparecer en otras ocasiones, en la parte expositiva.

Son muy exhaustivos los detalles de los negocios contractuales por cuanto han de quedar perfectamente aclaradas las contraprestaciones a que se obligan las partes contratantes. Del mismo modo es constante en las cartas de poder aclarar si el apoderamiento es general o especial, y que cierren el dispositivo con una fórmula de confianza en las actuaciones de sus representantes, comprometiéndose a respetarlas, y que refuerzan con una especie de cláusula coercitiva, mediante la cual obligan sus bienes en garantía de que cumplirán lo actuado por sus procuradores ${ }^{94}$.

En los documentos de derecho privado, excepto en aquellos en los que el escribano ha sido requerido por las partes para dar fe de un hecho acontecido en su presencia, y que denominamos en general como Actas, encontramos al final del dispositivo, aunque no sea infrecuente su dispersión, una serie de cláusulas, todas ellas de las que pretenden asegurar el cumplimiento de la acción jurídica, sin dejar resquicio alguno al que pudieran acogerse los autores para dejar de cumplir las obligaciones adquiridas.

Según el tipo de negocio escriturado encontramos unas $u$ otras, o, lo que es práctica habitual, se observa la inclusión de más de una de estas cláusulas. Es frecuente que aparezca en primer lugar una cláusula de las llamadas renunciativas, por la cual el otorgante declina emprender cualquier acción posterior en contra de lo ahora acordado, así como a las leyes que pudieran favorecerle. Su redacción es diversa, a veces muy genérica, como la que aparece en una dote ${ }^{95}$, en algunas cartas de pago ${ }^{96}$, y en las obligaciones al cumplimiento de algún tipo de deuda anteriormente contraida ${ }^{97}$, que lo hacen a «las leyes», «a las dos leyes», o a «las le-

94 Puede servir de ejemplo la que se inserta en el n. 9: «...e todas las otras cosas, e cada una dellas quél faría e podria fazer presente seyendo, así en juizio commo fuera dél. E otorgó de lo aver todo por firme, so obligación dél e de sus bienes".

95 ก. 10

$96 \mathrm{nn} .11,16,57$

${ }^{37} \mathrm{nn} .6,12,17,23,24,25,33,35,36,37,40$ y 64 . 
yes del Derecho", sin más concreción ${ }^{98}$, y que se insertan en el campo de las cláusulas de «renuncia general» ${ }^{99}$. Los autores que se han convenido para elegir jueces árbitros renuncian "a la ley del albedrío de buen vieron" " 100 , " al albedrío del buen vieron e todos los renunciamientos que aqui pueden ser puestos" 101.

Las mujeres que otorgan cartas de poder, renuncian a los derechos específicos que las amparaban desde que fueron recogidos en el Fuero Real ${ }^{102}$ y las Partidas ${ }^{103}$, cuyo espíritu, en algunos aspectos, habia pasado a la vida jurídica castellana del senadoconsulto Veleyeno cuando legisló en temas relacionados con la defensa jurídica de las mujeres ${ }^{104}$. En nuestros documentos estas referencias aparecen ciertamente muy desfiguradas en su expresión literaria, lo que era un vicio general ${ }^{105}$, debido, sin duda, a la transmisión consuetudinaria que del Derecho Romano recibían los escribanos locales que se limitaban a repetir estas fórmulas mecánicamente en aquellos negocios con participación de mujeres, hasta convertirla en una mera cláusula de estilo sin más trascendencia que la de demostrar una ciencia que no tenían, deslumbrando a los incautos a la vez que engordaban las escrituras, percibiendo, así, mayores estipendios ${ }^{106}$ : "renunció la ley del Valeriano ${ }^{107}$; o un poco más explícita: «e renunció la ley del enperador Valeriano/Veliano» ${ }^{108 .}$

En las cartas de poder no faltan las cláusulas que pone el poderdante, relevando a los apoderados de cualquier compromiso en el que se pudieran ver invo-

${ }_{98}$ El Derecho a que se renuncia es el Derecho Real y, fundamentalmente, las Partidas, según expone A. Rodriguez ADRADOS, «El registro notarial», pp.169-170. Véase una breve explicación de estas “renuncias" en M. A. MORENo TRUJILLO, “Diplomática notarial en Granada», p. 111.

${ }_{99}$ Aunque no se encuentra ninguna mención a la ley que impedia una renuncia general, del tipo "E la otra ley en que diz que general renunçiaçión non vala». En el Liber sextus $(81, V, 12)$ las renuncias generales están declaradas nulas. J. M. PÉREZ-PRENDES, “"General renunciación non vala". Sobre doctrina y práctica en tiempo del ius commune", en Glossae. Revista de Historia del Derecho Europeo, 5-6 (1993-1994) 75-114, analiza algunas tipologias de las cláusulas renunciativas en las pp. 89-102. O. FENGER, Notarius publicus. Le notaire au Moyen Âge latin, Denemark, 2001, pp. 86-87.

$100 \mathrm{nn} .53,55$.

101 n. 51.

$1023,18,5$.

$1035,12,2$.

104 J. LALINDE ABADiA, "La recepción española del senadoconsulto Velleyano", en Anuario de Historia del Derecho Español, IV (1971) 335-371.

105 Según la opinión de J. Bono Huerta, Breve introducción , p. 65.

106 Este tipo de cláusulas se convirtieron en inseparables en la forma de hacer de los notarios, que repitieron como fórmulas hechas a lo largo del tiempo. Puede verse la opinión de J. M. PÉrez-Prendes, "Los criterio jurídicos de Cristobal Colón", en Congreso de Historia del descubrimiento, III, 1992, p. 451. J. LALINDE ABADIA, "La recepción española", p. 360.

107 n. 32.

108 nn. 31, 39. La referencia al "enperador Valeriano", se debe a una tergiversación en el lenguaje de la técnica notarial, pues con esta cita se está aludiendo a un conjunto de normas surgidas del senado. consulto Veleyano, que prestó especial atención, como sabemos, a la defensa jurídica de las mujeres. Véase: Digestum, XVI, I-II. Codex, IV, XXIX, cols. 1585 y ss, 918 y ss. Comentarios a la doctrina casuística de esta ley beneficiosa para las mujeres, asi como algunas referencias, puede verse en: J. BONO HUERTA, Breve introducción, pp. 64-66. J. LALINDE ABAdia, Iniciación histórica al Derecho español, Barcelona, 1983, pp. 690, 785-786; "La recepción española", pp. 335-371. P. FUENTESECA, Historia del Derecho romano, Madrid, 1987, p. 261; Derecho privado romano, Madrid, 1978, pp. 208-209. A. D'ORS, Derecho privado romano, Pamplona, 1973, pp. 454-455. F. Gutiérrez Alviz, Diccionario de Derecho romano, Madrid, 1948, p. 554. 
lucrados durante el ejercicio de su misión, bajo las expresiones de "toda carga de satisdar, so obligación de bienes", para que no sean requeridos por la justicia por las actuaciones que hayan de realizar en el ejercicio de su procuración.

En una mayor proporción, pues son menos los que las omiten ${ }^{109}$, encontramos cláusulas de obligación general, lo mismo en los negocios personales que en los contractuales. Como indica su nombre, son el reflejo literario del compromiso formal del otorgante o, en su caso, al que han llegado las partes intervinientes poniendo como avales sus bienes e incluso sus personas como garantía de que cumplirán lo dispuesto. Su redacción es muy sencilla y estereotipada, referida a los bienes poseídos en el momento de la actio, pero que, frecuentemente, se extiende a los que se pudieran poseer en el futuro. Es frecuente, cuando interviene más de un sujeto, que se obliguen conjunta e individualmente, "de mancomún», y "cada uno por el todo".

Junto a estas obligaciones generales, y en ocasiones en los mismos negocios, encontramos otras más concretas; por ejemplo, cuando en una carta de aprendiz ${ }^{110}$ el tío del menor sale como avalista, "obligando sus bienes" ante el maestro que lo recibe como alumno; o cuando los que se avienen a la elección de jueces árbitros se obligan, bajo pena pecuniaria para la parte "obidiente" de aceptar lo dispuesto por los jueces elegidos. También se encuentran los sometimientos a la justicia, y la autorización para que actúen sin dilación en el caso de no observar las "obligaciones" autoimpuestas: "E sobre ello dieron poder a qualquier juez 0 alcalde / dio poder a qualquier justiçia para la execuçión »"11. No son pocos los casos que acompañan a estas cláusulas obligativas de penas pecuniarias, materiales y espirituales que las refuerzan.

Otros documentos precisan de cláusulas específicas. Así lo vemos en un cumplimiento de mandato ${ }^{112}$, que ha de poner una de emplazamiento instando a su obsenancia. Una cláusula parecida se inserta en todos los juramentos, pero en estos reforzada con penas pecuniarias "del doblo", y espirituales, "más so pena de perjuros e infames" "113, "so pena de perjuros e de infamias e de menos valers ${ }^{114}$.

La mayoría de los asientos de derecho privado, antes de la nominación de testigos, introducen una especie de cláusula corroborativa, de redacción escueta y sencilla, utilizada en Castilla como prueba de garantía que suprimía el resto de cláusulas complementarias ${ }^{115}$. Normalmente se trata de dejar constancia, de forma general, del "otorgamiento" de una "carta firme", aunque en ocasiones se preci-

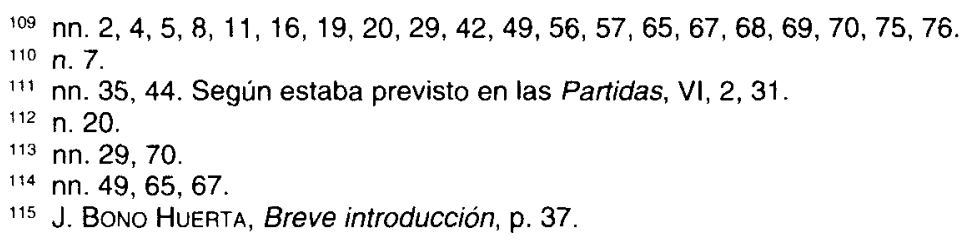


sa el tipo diplomático, "carta de compromiso firme" 116, "carta de pago firme» 117, "Carta de procuración/poder bastante/firme» ${ }^{118}$. Si se trata de asuntos contractuales, que precisan de un original múltiple, la redacción se explicita algo más, incluso para remarcar ese aspecto de «firmeza" que se quiere dar al documento, "dos contratos firmes, tal el uno commo el otro" "119; "dos cartas firmes de un tenor» ${ }^{120}$. Hay algunos casos con indicación de haberse confeccionado ad laudum sapientis ${ }^{121}$, que en nuestros documentos se explicitan como "fechas a consejo de sabios, tal la una commo la otra» 122; "carta de pago e de fin e quito de todo ello, firme e bastante, fecha a consejo de sabios" ${ }^{123}$, según se conocía en la práctica notarial castellana ${ }^{124}$.

El auctor puede hacer resaltar la petición, o rogatio, que ha recibido para la confección del documento: “...otorgaron un recabdo firme tal qual pronunçiaron, signado de mi signo" ${ }^{125}$. Lo mismo en los requerimientos ${ }^{126}$ y actas ${ }^{127}$, siendo un claro ejemplo: «E de commo pasó, los sobredichos frayres pidieron a mí, el dicho escrivano, que ge lo diese así para guarda del derecho del dicho convento, e yo diles ende este, que fue fecho día e mes e anno susudicho" ${ }^{128}$; aunque normalmente se trata de la simple manifestación de la solicitud de entrega documental, por ejemplo: “E desto, en cómmo pasó, amas las dichas partes pidiéronlo por testimonio» 129

En algunos asientos que tienen su origen en una actuación judicial, se deja constancia del mandato pronunciado por la autoridad competente para que el escribano entregue el documento que servirá de prueba de lo actuado; por ejemplo, en la petición de tutoría ${ }^{130}$, se «manda» dar "una carta de tutela bastante e firme, tal que requiere semejante negoçio".

Se cierra el tenor documental con la nómina de testigos. Ya se ha dicho que no aparecen suscripciones sino la exclusiva mención de los tres estipulados por la ley ${ }^{131}$. De ellos se indican los datos esenciales para su identificación, como son los nombres, apellido, frecuentemente con topónimo de origen, y la vecindad; tampo-

116 ก. 51

117 ก. 56

"Excepto la n. 61.

119 n. 41.

120 n. 63.

121 Quizá estemos ante la presencia de documentos redactados por juristas particulares y dados posteriormente al notario para su autorización y asiento en el registro. Véase J. Bono HuERTA, Breve introducción, pp. 49-50.

122 ก. 4.

123 ก. 11.

124 J. BONO HUERTA, Breve introducción, p. 50.

125 n. 47.

${ }^{126} \mathrm{nn} .19,75,76$.

$127 \mathrm{nn} .2,50,72$

128 ก. 2.

129 ก. 5.

130 n. 34 .

131 Se sigue asi lo que estipulaba el Fuero Real, 2, 9, 1. 
co es infrecuente añadir la filiación y la profesión. Si en alguno de ellos concurre alguna circunstancia especial para su mejor identificación, también se hace constar; es el caso de un "francés» "132, o del que es conocido como "el Çeço" "133, o el que se identifica como "caballero de maça de nuestro sennor el Rey» ${ }^{134}$. En algunos casos suele aparecer un cuarto testigo ${ }^{135}$ que suele ser el escribano actuante, quien se identifica con la clásica fórmula de "e yo... escrivano" 136; mientras que también hemos visto aparecer únicamente dos testigos ${ }^{137}$, uno de los cuales puede ser escribano ${ }^{138}$. Algunas singularidades son la mención de cuatro testigos y "todos cuatro escrivanos", entre ellos el actuante, que se citan en negocios jurídicos, una sentencia ${ }^{139}$ y en la publicación de una decisión judicial ${ }^{140}$; así como la presencia de "otros vecinos de la dicha çibdat de Cuenca" que se destaca en un testimonio notarial ${ }^{141}$. Si se escrituran simultáneamente dos negocios del mismo autor, en el segundo, la mención a los testigos se hace por referencia al primero: «Testigos, los sobredichos» ${ }^{142}$.

La nomina testium pone fin al tenor documental, sin embargo hay algunos documentos que han incluido algunas otras cláusulas o diligencias, todas con el fin común de reforzar su actio, bajo un juramento que ya se ha expresado en el desarrollo del tenor, y todas se realizan ante la mirada de los testigos que han concurrido al desarrollo del negocio principal mediante la misma fórmula: «Testigos, los sobre dichos".

En un contrato ${ }^{143}$ se deja constancia del juramento hecho por los autores, bajo sanciones espirituales de "perjuros e infames". En otra ocasión, ahora un requerimiento ${ }^{144}$, el escribano deja constancia de la respuesta dada por el requerido a la demanda que se le ha puesto y de las condiciones que ofrece para su cumplimiento, así como de la aceptación del requiriente. Si se trata de una toma de posesión ${ }^{145}$, encontramos la manifestación del juramento hecho por la anterior propietaria de no abandonar la ciudad, bajo las penas espirituales de «perjura e de

132 ก. 43.

133 ก. 2.

134 ก. 72

135 nn. $4,17,25,45,67,68,69$.

136 nn. $3,7,14,15,31,32,35,38$

137 nก. $49,65$.

$130 \mathrm{nn}$. 5. En las Partidas, 3, 18, 54, se estipulaba la presencia de dos testigos que fueran escribanos, aunque en realidad parece que se conforman con dos testigos cualquiera al regular la nulidad formal y el valor probatorio $(3,18,111-114)$. Véase este comentario en A. RODRIGUEZ ADRADOS, “El registro notarial», p. 178.

139 ก. 48

140 ก. 42 .

141 ก. 2.

$142 \mathrm{nn} .12$ y 37

$143 \mathrm{~N}, 47$.

144 n. 19. "E luego el dicho Pero Fernández dixo al dicho alguazil que dé los dichos balandranes al dicho Femando para que los tenga en prenda de los maravedís que le deve, e él dixo que consentía e consintió on ello". En los otros requerimientos (nn. 8, 75, 76) esta parte documental tiene lugar antes de la nominación de los testigos.

145 n. 72. 
menos valer" ${ }^{146}$. Los documentos que hemos denominado como obligaciones son los que presentan una mayor intromisión de estas fórmulas que podemos llamar complementarias. Generalmente se trata de juramentos, "para mayor firmeza» ${ }^{147}$. Uno de estos documentos ${ }^{148}$, sin duda realizado por un menor, añade a la consabida fórmula de juramento otra de tipo renunciativo, ya que hace expresa mención de «non allegar menoría de edad nin otra razón alguna" para cumplir con la obligación que ha contraido ${ }^{149}$.

Una vez realizado globalmente el análisis diplomático de los documentos escriturados, los podemos separar por grupos según su tipología, cuando está bien definida, o según la materia jurídica del negocio, lo que nos ha llevado, en ocasiones, a realizar un sincretismo entre ambas opciones. De esta forma hemos elaborado un cuadro clasificatorio en el que se ha tenido en cuenta la escrituración de actos entre particulares y la de aquellos otros que surgen del ámbito de los tribunales ${ }^{150}$ :

A. Documentos de Derecho privado.

I. Actas:

I.1. Testimonio notarial ${ }^{151}$ (n. 2).

II. Contratos:

II.1. Contratos:

- de aprendiz (n. 7).

- de soldada (n. 60).

- de "viñadería" (n. 47).

- de «ama de cria» (n. 63).

II.2. Arbitraje (nn. 51, 53, 55).

II.3. Juramento (nn. $29,49,65,67)$.

${ }^{146}$ El desarrollo del juramento tiene un tenor completo: Data referenciada, intitulación y dispositivo reforzado por las cláusulas sancionales de penas espirituales, asi como la petición de testimonio y la comparecencia de testigos.

147 n. 25. «para mayor firmeza e seguridad»; n. 40. «E por más seguridad que pagará al plazo, fizo juramento...".

148 ก. 33.

149 Se trata de una renuncia a los beneficios legales que protegian a los menores de 25 años de edad. Véase, M. A. Moreno TrujlLlo, "Diplomática notarial en Granada", p. 106.

150 Hemos tenido en cuenta algunas clasificaciones realizadas en estudios de registros o de documentación notarial en general: J. BONO HUERTA, Los archivos notariales, pp. 29-41. M. A. MORENO TRUJiLlo, Documentos notariales de Santa Fe, pp, 68-72. P. Ostos, M. L. PARDo, Documentos y notarios de Sevilla en el sigio XIV (1301-1350), Sevilla, 2003, pp. 61-62. M. D. Rojas Vaca, Un registro notarial, pp. 51 y ss. M. Vázquez Bertomeu, Notarios, notarias, p. 69. R. Pérez-Bustamante, El registro notarial de Santillana, Madrid, 1984, p. 51; El registro notarial de Dueñas, Palencia, p. 42.

151 En ambos casos el notario levantará acta de los hechos que se relatan protagonizados por los solicitantes de su presencia cualificada, con el fin de que sirva de testimonio, tal es el término jurídico que encabeza los asientos, por si hubiera lugar a posteriores reclamaciones por el incumplimiento de las obligaciones que contrae un tercero, que aparece en el desarrollo negocial pero sin tomar parte directa en él, no obstante ser el sujeto de la directio. 
II.4. Obligación ${ }^{152}$ (nn. 12, 17, 21, 23, 24, 25, 33, 36, 37, 40, 45, 52, 58, $64,73,74)$.

III. Derecho de familia.

III.1. Carta de dote (n. 10).

III.2. Desposorio (n. 41).

IV. Representación de la persona.

IV.1. Carta de poder (nn. 3, 9, 13, 26, 27, 28, 31, 32, 39, 46, 54, 61, $62,66,77)$.

V. Sobre el crédito real o personal.

V.1. Censo enfitéutico (n. 4).

V.2. Reconocimiento de deuda (nn. 50,57).

V.3. Carta de pago (nn. 11, 16, 56).

V.4. Requerimiento ${ }^{153}$ (nn. 8, 75, 76).

VI. Recaudo ${ }^{154}$ (n. 1).

VI.1. Anulación de arbitraje (n. 5).

152 Diplomáticamente tienen un desarrollo clausular semejante, y es el epígrafe más utilizado por nuestro escribano para englobar negocios juridicos diferentes y que no encajan en otras categorias usuales. Véase coincidente opinión, aunque para una época posterior, en M. A. MORENO TruJILLO, «Diplomática notarial en Granada", p. 114; Documentos notariales de Santa Fe, pp.66, 68, 79-80. R. PÉREZBustamante, El registro notarial de Santillana, pp. 56-58. También la definición desde el punto de vista jurídico y los matices que se encuentran del término aportados por $V$. LAGÜÉNS GRACIA, Léxico jurídico en documentos notariales aragoneses de la Edad Media (siglos XIV y XV), Zaragoza, 1992, p.187.

${ }^{153}$ Con esta denominación aparecen cuatro asientos. El motivo que ha ocasionado la intervención notarial y su escrituración registral es distinta. En tres casos ( $\mathrm{nn} .8,75,76)$, los interesados acuden a la oficina notarial de motu proprio, al sentirse perjudicados por un tercero al que "requieren" para que haga frente al agravio del que se dicen perjudicados. En el tercero (n. 19) el requerimiento parte de una autoridad competente que pretende detener un embargo que pesa sobre ciertos bienes del requerido, del que demanda una pronta respuesta, de lo contrario ejecutará el embargo. Véase V. LangüÉnS Gracia, Léxico jurídico, p. 233. A. Riesco TERRERO, Vocabulario científico-técnico de Paleografía, Diplomática y ciencias afines, Madrid, 2003, p. 369.

154 Bajo el término «recabdo", que aparece encabezando los epigrafes de doce asientos, encontramos tipologías diplomáticas diferentes que, en la mayoría de los casos, se corresponden con distintos negocios perfectamente establecidos en otros asientos. El que algunos negocios se hayan escriturado bajo ese calificativo no obstaculiza su análisis dentro del tipo al que pertenecen, pues no altera en nada básico la estructura que comparte con sus homogéneos. Teniendo en cuenta la definición que se propone del término «recabdo» pensamos que no es más que una forma juridica a la que han recurrido algunos autores de nuestros documentos para reforzar el trámite del negocio escriturado, o dejar constancia de una actuación ante la autoridad competente. Asi la definición que propone la Enciclopedia Jurídica Española, Barcelona, 1910, tomo 26, p. 613, «RECAUDO: Equivale a caución, fianza o seguridad, y también significa precaución y cuidado"; Idem, tomos 4 y 5 refundidos, p. 945, “CAUCION: Es el aseguramiento de una obligación. La Ley 10, tit. XXII, Part. 7. la definía: "Seguramiento que el deudor ha de facer al señor del debdo, dándole fiadores valiosos o peños". En este limitado concepto no se distinguen las fianzas". Pueden verse también las definiciones propuestas por: A. RIEsco TERRERo, Vocabulario, p. 359, «Diligencias, cauciones y medidas a tomar para que un procedimiento o pleito se ejecute conforme a derecho", y Diccionario de autoridades: "Recaudo. Se toma también por lo mismo que recado, que es como ahora se dice». "Recado: Se toma asímismo por el instrumento o papel de justificación que se presenta para cobrar o aclarar algún derecho". 
VI.2. Obligación (nn.6, 35, 44, 59, 68, 69, 71).

VI.3. Contrato: iguala médica (n.38).

VI.4. Reconocimiento de deuda (n. 43).

VI.5. Juramento (n.70).

VII. Sentencia (n. 48).

B. Documentos de Derecho procesal.

I. Actas:

I.1. Pregón de almoneda ${ }^{155}$ (nn. 14, 15, 18, 22, 30).

I.2. Testimonio (n. 42).

I.3. Toma de posesión (n. 72).

II. Sobre el crédito real o personal.

II.1. Cumplimiento de mandato (n. 20).

II.2. Requerimiento ${ }^{156}$. (n.19).

III. Derecho de familia.

III.1. Solicitud de tutela y curatela (n. 34).

IV. Sentencia (n. 48).

\section{ASPECTOS SOCIALES}

Hasta aqui hemos cumplido con el fin propuesto de analizar el Registro de Simón Fernández de Moya desde el punto de vista diplomático; sin embargo, no queremos dejar de hacer algunos comentarios a los aspectos sociales ${ }^{157}$ que se vislumbran en los negocios jurídicos analizados desde la fría óptica del diplomatista. Pero no nos hagamos ilusiones, porque la visión que de la vida ciudadana conquense nos muestra el mencionado Registro es reducida en el tiempo, apenas cinco meses, y también en cuanto a la cantidad de asuntos o negocios, pues de la clientela de un sólo escribano se trata. En los asientos registrados vemos fotogra-

155 Podemos pensar que son verdaderos testimonios notariales donde queda constancia de las ofertas acontecidas durante los tres pregones preceptivos, aunque en los de la segunda venta, por alguna causa que ignoramos, únicamente hayan quedado asentados dos pregones. En los asientos se recogen los testimonios de las ofertas o pujas que se hacen por las mercancias pregonadas y la adjudicación de los bienes al mejor postor.

158 Véase nota 153.

157 Un estado de la cuestión sobre bos aspectos sociales que los registros notariales proporcionan al estudioso de la época medieval, puede verse en R. CÓRDOBA DE LA LLAVE, "El reflejo de la sociedad bajomedieval en los protocolos notariales andaluces", Aragón en la Edad Media. Porspectivas actuales sobre las fuentes notariales de la Edad Media, Zaragoza, 2004, pp. 83-102, que aunque referido a un espacio geográfico concreto es perfectamente extrapolable a otras zonas peninsulares. También es de interés el estudio de los aspectos sociales que sobre un registro extrae R. MOsti, Un notaio romano del Trecento. I protocolli di Francesco di Stefano de Caputgallis (1374-1386), Roma, 1994, pp. XIII-L. 
mas, intermitencias de la vida cotidiana de la ciudad de Cuenca, que, eso sí, pueden ayudarnos a entrever las relaciones de todo tipo que se tejen entre sus habitantes, en general gentes sencillas que realizan negocios jurídicos de escaso peso económico. De los otros dos lugares, Huete y Fuentes, donde fedata negocios nuestro escribano, sería verdaderamente atrevido hacer cualquier observación que vaya más allá del simple comentario de lo que son los negocios en sí mismos; no obstante, debemos señalar el interés que revisten las actuaciones en Huete, toda vez que hacen referencia a asuntos económicos relacionadas con la cobranza de las rentas reales y con el "oficio de la escribanía" en la tierra de la Orden de Santiago y de otros lugares de la tierra de Huete.

Con todo, nos parece que se nos abren las puertas para introducirnos, aunque sea de puntillas, en la vida privada de algunos de nuestros antepasados de la Ciudad de las Hoces, para verlos actuar en los más variados compromisos y situaciones que la vida cotidiana les planteaba. Por ejemplo, conocemos la entrega de 300 florines de oro, que como aportación dotal hace una mujer a su marido, de los "bienes propios" que había heredado de su padre ${ }^{158}$; y se nos permite asistir a un «desposorio por palabras de presente» ${ }^{159}$, y ser testigos del ritual seguido «segund manda la dicha santa Iglesia de Roma» ${ }^{160}$, en una realidad cotidiana de la que no han quedado demasiados testimonios escritos ${ }^{161}$, más de un siglo antes de que estuviera perfectamente regulado por las leyes canónicas que implantó el Concilio de Trento ${ }^{162} y$, por lo tanto, de su inscripción en los parroquiales "Libros de Matrimo-

159 n. 10. J. MARTINEz GiJón, «El régimen económico del matrimonio y el proceso de redacción de los textos de la familia del Fuero de Cuenca», en Anuario de Historia del Derecho Español, 29(1959) 64-66, dice que estas aportaciones dotales de la mujer únicamente las recoge el Fuero de Madrid, sin duda influenciado por las prácticas jurídicas toledanas, que también dejaron notar su influencia en el Fuero de Cuenca. Puede verse, M. A. Alonso, "La dote en los documentos toledanos de los sigios $x \| 1-x V$ ", en Anuario de Historia del Derecho Español, 48 (1978) sobre todo pp. 387-399.

${ }_{159}$ n. 41. En esta ocasión la dote que entrega el padre de la novia es sustanciosa, demostrando una buena posición económica. Se compone de bienes urbanos y rústicos: en la ciudad casas con sus bodegas y vajillas, corrales y establos; y en el campo, majuelos y viñas. De todos ellos se indica exactamente su situación, tanto las casas en la ciudad mediante los «aledaños" que se especifican claramente, como las propiedades rústicas mediante las correspondientes "surqueras".

160 El Sinodo que se acababa de promulgar por el obispo de la Diócesis, Álvaro de Isorna, en 1422, determina lo siguiente cuando habla del sacramento del matrimonio: "Sequitur de Sacramentis...Quintum matrimonium, quod debet recipi in facie Ecclesie ab his qui in statu coniungali volunt permanere". Recogido en el Libro de los Estatutos y loables costumbres de esta Sancta Yglesia de Cuenca, A.C.C. III. Libs. 364, f. XXV.

161 Aunque sea de un ámbito geográfico distinto al castellano, y para época anterior, aporta unos datos muy interesantes el extraordinario trabajo de J. BAuCELLS I REIG, Vivir en la Edad Media: Barcelona y su entorno en los siglos XIII y XIV (1200-1344), I, Barcelona, 2004, pp. 665 y ss. M. C. Garcia HeRAERO, Del nacer y el vivir. Fragmentos para una historia de la vida en la baja Edad Media, Zaragoza, 2005, donde recoge algunos de sus anteriores trabajos. Concretamente ahora nos interesa «Las capitulaciones matrimoniales en Zaragoza en el siglo XV», pp. 133-154, publicado con el mismo título en En la España medieval, 5 (1986) $381-398$.

162 El matrimonio Sacramento fue definido en el Concilio de Trento: sesión 24, Decreto Ne temere: "Si quis dixerit, Matrimonium non esse vere et proprie unum ex septem legis Evangelicae Sacramentis a Christo Domino institutum, sed ad hominibus in Ecclesia inventum; neque gratiam conferre; anathema sits. Ya en el siglo XI, y, sobre todo, desde el siglo XIII se empezó a tener claro que el matriminio tenía carácter sacramental. No es un tema en el que ahora debamos profundizar, pero una rápida visión de las autoridades medievales que pusieron los cimientos de la definición conciliar puede verse en J. GAUDEMET, 
nio», cuya obligación para los párrocos quedó igualmente establecida en dicho Concilio ${ }^{163}$.

Es conmovedor escuchar la voz preocupada de un joven, "mayor de catorze annos e menor de 25 ", que acude ante la autoridad competente para que se conceda a su tío paterno la tutela y curatela ${ }^{164}$ sobre él y sus hermanos pequeños, ya que su madre ha contraido nuevo matrimonio después de enviudar ${ }^{165}$. Compartimos la tristeza de una mujer que se ve obligada a abandonar su casa ${ }^{166}$ interpretando un simbólico ritual preñado de contenido jurídico, donde el nuevo propietario es recibido a la puerta de la casa por la dueña para realizar el cambio de propietarios: «la qual tomó de la mano al dicho... e introlo dentro de las dichas casas; e luego el dicho..., en usando de la dicha posesión, tomó de la mano a la dicha...e echola fuera de las dichas casas. $E$ en usando de la dicha posesión abrió e çerró las puertas de las dichas casas".

También nos es dado contemplar una vertiente de la práctica de la medicina, la que podriamos considerar como «privada», semejante a lo que era habitual no hace tantos años en nuestras sociedades, mediante el contrato ${ }^{167}$ que se realiza entre un enfermo y el médico al que acude para ser atendido en su enfermedad. Se describe con detalle la dolencia, en este caso "una llaga" en la ingle, y se estipulan las condiciones de la iguala entre médico y paciente: la cantidad que ha de percibir el "çerujano" que se comprometa a curarla en un tiempo determinado y la cantidad que se le ha de hacer efectiva a los plazos convenidos, pero condicionados a la recuperación de la salud.

Nos permite, asímismo, acercarnos a la vida económica de la ciudad, asentada sobre el sector agrario y artesanal, y ver sus relaciones contractuales y transacciones comerciales, arrendamientos, censos, relaciones entre patrón y trabajador; los préstamos y las deudas, sus motivos y formas de pago ${ }^{168}$, valor de los productos agrícolas, las monedas usuales, el maravedi, "las blancas" y su equivalencia, "dos blancas hacen un maravedi» ${ }^{169}$, y el florín de oro, del que siempre se especifica que es del "peso e cunno de Aragón", pero del que no es fácil hallar

El matrimonio en Occidente, Madrid, 1993, pp. 220-223. Hay suficiente bibliografía al respecto en el reciente libro de M. C. Garcia Herrero, Del nacer, ahora remito al capítulo "Matrimonio y libertad", pp. 107-132, ya publicado en Aragón en la Edad Media, 12 (1995) 267-286, con el título «Matrimonio y libertad en la baja Edad Media aragonesa".

${ }_{163}$ Decreto Tametsi, de la sesión 24, correspondiente al 11 de noviembre de 1563: «Habeat parrochus librum in quo coniugum et testium nomina, diemque el locum contracti matrimonii describat, quem diligenter aoud se custodiat".

${ }_{164}$ n. 34 . Véase la legislación sobre esta dicotomía en A. MERCHÁn Álvarez, La tutela de los menores en castilla hasta fines del siglo XV, Sevilla, 1976, pp. 209-219.

165 Véase la legislación sobre este supuesto en lbidem, idem, pp. 153-157.

166 ก. 72.

167 ก. 38. La realización de "contrato" entre enfermo y médico era algo habitual en la sociedad medieval. Véase L. Garcí Ballesteros, Artifex factivus sanitatis. Saberes y ejercicio de la profesión de la medicina en la Europa pluricultural de la baja Edad Media, Granada, 2004, pp. 61-62, 71-72.

${ }_{168}$ Las escrituras de obligación son las más frecuentes a la hora de informarnos sobre los préstamos, promesas de pago, reconocimientos de deudas atrasadas, etc.

169 ก. 52. 
su equivalencia ${ }^{170}$; además de observar una práctica habitual a la hora de resolver algunos litigios entre particulares, que acuden a soluciones concertadas por jueces árbitros en lugar del recurso al lento y gravoso mecanismo judicial ${ }^{171}$.

No son muchas las noticias sobre precios y salarios que hemos encontrado, además de referirse a un reducido número de productos y servicios; por lo tanto, somos conscientes de que lo entresacado del Registro no deja de ser anecdótico. A este respecto hay algunos contratos de cierto interés, como el que se produce entre los "sennores" de las viñas y dos vecinos de Cuenca ${ }^{172}$, que recibirán tres maravedís por cada aranzada de viña que custodien. Otro contrato ${ }^{173}$ nos proporciona noticias sobre las condiciones estipuladas entre el «maestro" y el padre de un joven aprendiz de platero: los seis años de duro y fiel aprendizaje bajo las órdenes del maestro y los cuidados que éste le ha de proporcionar en vestidos y alimentos mientras permanezca en su casa, además de 300 maravedís y uun balandrán, unas gramañas de paño cárdeno de Cuenca y un jubón de cotona, nuevos" cuando terminen los seis años pactados de aprendizaje. Mientras que una mujer contratada ${ }^{174}$ como ama de cría recibirá un salario mensual de 50 maravedís durante los 18 meses que durará el amamantamiento. También sabemos que un hombre se contrata por 1000 maravedís, más comida y bebida, por un año de trabajo en "todas las cosas que se le mandaren" ${ }^{175}$.

Como es natural, no pueden faltar las referencias a los productos propios de un sistema de economia agraria, aunque, de nuevo, sea escasa su presencia. Los cereales son el alimento fundamental en estas sociedades, por lo tanto son variadas las menciones al trigo, a la cebada y al centeno; pero en concreto, y referido a sus precios, se pagan 20 maravedis por una fanega de pan, la mitad de trigo y la mitad de cebada ${ }^{176}$; mientras que por la deuda de una renta ${ }^{177}$ se exigen 60 maravedís por cada fanega de trigo y 40 por cada fanega de cebada y centeno, pero en otra circunstancia parecida el precio es de 50 maravedís por fanega de trigo ${ }^{178}$. Tambien encontramos referencias a los cultivos vitivinícolas, situados hacia el Este de la ciudad conquense, en el «camino de Mohorte» ${ }^{179}$ y en el "pago de Cabeza Molina» ${ }^{180}, y$

170 ก. 50

171 Puede verse, A. Merchán Álvarez, El amitraje. Estudio histórico-jurídico, Sevilla, 1981, sobre todo el cap. VI, pp. 149-169; "La alcaldía de avenencia como forma de justicia municipal en el Derecho de León y Castilla", en La ciudad hispánica durante los siglos XIII al XVI, I. Actas del coloquio celebrado en La Rábida y Sevilla del 14 al 19 de septiembre de 1981, Madrid, 1985, pp. 67-91.

172 ก. 47.

173 ก. 7.

174 ก. 63.

175 ก. 60.

176 ก. 50.

177 ก. 75.

178 ก. 8.

179 ก. 41.

${ }^{180}$ En este pequeño cerro, a la izquierda de la salida de Cuenca hacia Cañete, donde en la actualidad se asientan unos depósitos de agua, aparecen situados desde los primeros momentos de la Cuenca cristiana cultivos de viñas, según la documentación más antigua de que disponemos. Cfr. F. A . CHACÓN GómezMONEDERO, "El patrimonio rural de la Iglesia de Cuenca. Siglos XI1-XIII", en Cuenca, 30 (1987, II) 68. 
una viña nueva o «majuelo en el pago de Grillera» ${ }^{181}$. Las precauciones que se tomaban para su guarda y custodia, y que vemos en el contrato ${ }^{182}$ que a este respecto tiene lugar, además de la presencia de algunos regidores en el momento de la actio, refuerza la importancia que para la vida ciudadana tenían estos cultivos ${ }^{183}$.

Otros cultivos que aparecen son una mención a la «çerondaja», quizá refiriéndose a algunos cultivos de legumbres o árboles frutales ${ }^{184}, y$ «tres forcas de çebollas" que se deben, junto a una cantidad de marevedís, por carta de pago ${ }^{185}$; además de encontrar una indirecta mención al cultivo del olivo y a su transformación en aceite en alguna almazara familiar. La noticia nos viene de una deuda ${ }^{186}$ de la que son protagonistas, junto a cierta cantidad de maravedis, "quatro alhonbras de almulque». Es cierto que la noticia no es clara, pero pensamos que se puede referir a unas esteras circulares de esparto, con un orificio en el centro, por donde se introducen en el eje de las prensas de las almazaras, con el fin de separar por capas las aceitunas que se han de triturar y evitar que el desecho, que recibe el nombre de alpechín o “almurca» ${ }^{187}$, se mezcle con el aceite.

Junto a la agricultura, la ganadería hace su aparición de forma testimonial. Es curioso que no se mencione ningún negocio relacionado con la ganadería ovina, de

181 n. 41. Está situado hacia el Oeste, junto al río Jucar.

182 ก. 47.

183 Ya se observa en el FUERO de Cuenca, al dedicarles todo el cap. IV, esta preocupación por el cuidado de las viñas, que extracta M. RIU, "Agricultura y ganaderia en el Fuero de Cuenca", en Cuenca y su territorio en la Edad Media. Actas del I Simposio Internacional de Historia de Cuenca (Cuenca, 5-9 de septiembre de 1977), Madrid-Barceiona, 1982, p. 174. Véanse algunas notas a este respecto en Y. GuERRERO NAVARRETE, J. M. SÁnchez Benito, Cuenca en la Baja Edad Media: un sistema de poder, Cuenca, 1994, p. 175-176.

184 n. 16. Aunque el término no es claro, podemos aventurar las siguientes definiciones: Se podría pensar en un cultivo de ciruelas, si le hacemos proceder del latín cereola, "sitio poblado de ciruelos" (M. SECo, Léxico hispánico primitivo (siglos vil al xil), Madrid, 2003, p. 137); pero creemos que es más acertado referirlo a toda clase de "frutos tardíos", tomando su procedencia de "seronda", cuya etimología procede del adjetivo latino serotinus, tardío, "terreno donde los frutos maduran tarde", y más concretamente referida a legumbres tales como «garvanzos y havas, arvejas y otras legumbres que se siembran tarde", o a "las cosas menudas y de poco valor", "los granos y semillas para alimento del ganado", según la definición que de "Serondaja", "Çarandajas", ofrece J. COROMINAS, J. A. PASCUAL, Diccionario crítico etimológico castellano e hispanico, V, pp. 226-227. Con etimología de un derivado del latín serus, tardío, tendríamos “seroja”, pero no creemos que se trate del término que buscamos, pues está referido a la «hojarasca seca que cae de los árboles. Residuos o desperdicios de la leña. Sinónimo de hojarasca, de la leña menuda, haces, gavillas, ramillas, astillas, cepas y otros desperdicios. También se han llamado seroja las astillas que con suficiente miera sirven para fabricar la pez en los hornos o pequeras". Cfr. Enciclopedia Universal llustrada Europeo-Americana, LV, Madrid, 1989, pp. 545-546.

185 ก. 26.

186 ก. 54.

187 Según el Diccionario de Autoridades, I, pp. 237-238, «Almurca: El zumo de las azeitunas exprimidas, que se aparta del aceite por ser más pesado, y se dexa escurrir por inútil. Comúnmente en Andalucia y otras partes se llama alpechín. Esta voz es tomada del latino amurca, que vale lo mismo, pero está anticuada. La almurca es la hez de las aceitunas". Teniendo en cuenta esta definición, y que entre los utensilios que se precisan en los molinos o almazaras se encuentran unas esteras para separar por capas las aceitunas, o "capachos/as" de esparto de forma circular con una boca por donde se introducen la aceitunas, uniformemente distribuidas, para ser prensadas y evitar la mezcla del aceite y de las "heces", pensamos que las "alhonbras de almulque" bien podrian estar haciendo referencia a estas esteras o capachos/as. Véase J. Martinez Marin, J. A. Moya CorRaL, El léxico del olivo y la almazara en la provincia de Jaén, Granada, 1982, p. 24; en la lám. XIII, 25, se observa uno de estos capachos/as circulares que al estar vacíos parecen esteras o alfombras. 
tanta importancia en la tradicional economía conquense ${ }^{188}$, a no ser el arrendamiento de la hierba del término de Fuentes que desean solicitar dos de sus vecinos ${ }^{189}$. Por lo demás, sabemos de la obligación ${ }^{190}$ de pagar una deuda de diez florines de oro, por la compra de «un roçin, su color alazán, con sus tachas, buenas e malas, commo huesos en talego"; mientras que un mulo que se había comprado para el Comendador de Santiago de Cuenca, costó seis florines más, es decir 16 florines ${ }^{191}$. El precio de una mula se nos dá en maravedís, más de 400 , pues esta es la cantidad que se reconoce haber recibido como resto de lo que quedaba por pagar del precio total en que se había adquirido ${ }^{192}$.

Las industria textil, que había tenido su origen en la etapa árabe, continuará en la Cuenca cristiana en progresivo ascenso, haciendo de la ciudad un foco de atracción para la mano de obra de los núcleos rurales próximos, que le permitirá crear una industria pañera muy apreciada en el mercado ${ }^{193}$. No es de extrañar, por lo tanto, que fabricantes y productos hagan su aparición en los negocios que escritura nuestro escribano. Unas veces será con ocasión de algunas compras de materia prima que realizan sus profesionales y otras por los compromisos que adquieren para la realización de algún tipo de trabajo, sin que falte la aparición de productos textiles como mudos testigos que sacan de apuros a sus adeudados dueños. En primer lugar nos encontramos con un «texedor de lienços", que no pierde la oportunidad de comprar en almoneda 194 "unos balandranes pardillos de panno de Cuenca, aforrados en panna blanca", por 80 maravedís, precio que suponemos inferior al real, teniendo en cuenta las circunstancias de su adquisición. En otra ocasión, un peraile se compromete ${ }^{195}$ a "adobar 28 pannos mercaderos", de los que se fabricaban en Cuenca, a razón de 50 maravedís por cada paño. Suponemos que el «balandrán" y el «jubón de cotonia", que ha de dar el maestro platero a su aprendiz cuando finalice su enseñanza ${ }^{196}$, serían confeccionados en Cuenca, pues sí nos consta que lo son "unas gramannas de panno de Cuenca, cárdeno" que también formaban parte del lote que se compromete a entregar; así como los "quatro pannos blancos en xerga", más "dos burieles adobados" que se pagaron por 2.032 maravedís que se adeudaban de la renta de la alcabala de la carne ${ }^{197}$.

188 Puede verse, J. M. SÁnchez Benito, Cuenca en la baja Edad Media, pp. 179-185

189 ก. 77.

190 ก. 6.

191 ก. 50.

192 ก. 57

193 Para todo lo relacionado con la industria textil en Cuenca es imprescindible la obra de P. IRADIEL MurugarRen, Evolución de la industria textil castellana en los siglos XIII-XIV. Factores de desarrollo, organización y costes de producción manufacturera en Cuenca, Salamanca, 1974. La denominación de los tejidos que aparecen creemos que son conocidos y fácilmente encontrables en el Diccionario de Autoridades; no obstante se puede consultar, por ejemplo, J. ALFA.U DE SOLALINDE, Nomenclatura de los tejidos españoles del siglo xil, Madrid, 1969.

194 ก. 14.

195 ก. 36.

196 ก. 7.

197 n. 43. Sabemos que a comienzos del siglo xvı se fabricaban en Cuenca "burieles", según recoge A. Rojo Vega, Guia de mercaderes y mercaderias en las ferias de Medina del Campo. Siglo xvi, Valladolid, 2004, p. 229. 
Junto a estas noticias sobre productos textiles autóctonos, encontramos menciones a otros foráneos, incluso de más allá de las fronteras hispanas, que nos hablan del comercio que llegaba hasta nuestra ciudad. No sabemos si fue fabricado en Cuenca «el panno blanco en filaza ordido, estanbre e trama lo que oviere menester, de buena lana e filaza areado" que se debía ${ }^{198}$ por la adquisición de "çierto lienço»; ni de dónde procedía la arroba de algodón por la que un jubonero pagó un total de 225 maravedís ${ }^{199}$. Sí nos es conocida la procedencia de «cinco varas de panno de Ypre turquesado", así como los 550 maravedís que costaron ${ }^{200}$; del mismo modo que conocemos la procedencia de «un panno de berví de Flandes verde" que un sastre compró por 600 maravedís ${ }^{201}$.

El territorio conquense tenía una elevada concentración de salinas, sobre todo en la zona de la Sierra ${ }^{202}$, de donde se extraía la sal, ese producto básico para la vida del hombre medieval, usado tanto en los condimentos de cocina como en la conservación de carnes y pescados; sin olvidar el papel tan importante que desempeñaba en todo lo que se movía en torno al mundo de la ganadería y en la industria del curtido y de la farmacia; sin embargo, en nuestro Registro únicamente aparece como protagonista en una ocasión en que se reclaman las rentas de las salinas del Obispado de Cuenca ${ }^{203}$.

Por último, debemos señalar la importancia que en Cuenca tenía el arte de la orfebrería, regulado ya en su Fuero ${ }^{204}$. En 1396 Enrique III, respondiendo a una petición del propio Concejo conquense, concede que la ciudad pueda tener «marco» y «marca» de plata, pero advirtiendo que el «marco» seria de igual peso que el de Sevilla y la "plata de ley de onze dineros e seis gramos", dejando en libertad al Concejo para elegir la «marca» que estimase oportuna ${ }^{205}$, siendo Cuenca quizá la primera ciudad de Castilla que antes tuvo marca oficial ${ }^{206}$.

Hacemos este breve comentario porque vemos frecuentemente a miembros del gremio de los plateros aparecer en el Registro que comentamos, tanto como

198 ก. 58.

199 ก. 17

200 n. 21

201 ก. 52

202 Una breve exposición de lo que hace a la extracción de la sal y ubicación de las salinas en el territorio conquense, propiedades y fiscalidad, así como la bibliografía clásica sobre lo relacionado con este producto, suficiente para evitarnos repetirla, puede verse en J. M. SÁNCHEZ BENITO, Las tierras de Cuenca y Huete en el siglo XIV. Historia económica, Universidad de Castilla La Mancha, [Cuenca], 1994, pp.175-181.

203 ก. 1

204 FUERO de Cuenca, p. 796, cap. XLII, V: «De aurificibus". Para todo lo relacionado con el mundo de la plateria conquense, ciertamente que para el siglo XVl, pues no hay ningún estudio para épocas enteriores, véase A. LópEz-YARTO ELIZALDE, La orfebrería del siglo Xvi en la provincia de Cuenca, Cuenca, 1998.

205 Cfr. F. A. Chacón Gómez-Monedero, Colección diplomática, pp. 365-366, n. 155. Por desgracia no conocemos ninguna pieza «marcada» de los últimos años del siglo XIV ni del XV, según los estudios realizados por A. LóPEZ YARTO ELIZALDE, La orfebreria de la provincia de Cuenca. El siglo XVI, Madrid, 1990 , p. 97; La orfebrería del siglo Xvi, pp. 29-37.

$206 \mathrm{Cfr}$. J. M. Cruz Valdovinos - B. Santamaria, “ Notas sobre la más antigua normativa profesional de los plateros sevillanos", en Andalucia moderna (siglos XVI-XVIII), I, Córdoba, 1974, p. 60. A. LOPEZ-YARTO ELIZALDE, La orfebrería del siglo XVI, p. 29. 
protagonistas de la actio de diferentes negocios, no siempre relacionados con su oficio, como siendo testigos de otros a los que son llamados. Tengamos en cuenta, además, que el único contrato de aprendiz ${ }^{207}$ que se documenta es, precisamente, para aprender el "ofiçio de la plateria» y, curiosamente, el joven que busca maestro entre los plateros conquenses es vecino de Sevilla, ciudad de la que no se puede dudar de su larga tradición y bien hacer en este arte. Algunos objetos de plata, sin duda fabricados por plateros conquenses, conocemos gracias a que se tuvieron que dejar como "prendas e pennos" hasta que se pagasen 4.000 maravedís que se adeudaban de renta de la alcabala de la carne ${ }^{208:}$ : setenta e nueve botonçillos de plata pequennos sobredorados e más tres medios botonçillos, quarenta esmaltejos pequennos, ochenta e dos botonçillos, a manera de morillas, dorados, çinquenta e nueve botones blancos de lavor sevillanos, catorze cucharetas, dos taças doradas labradas a cucharetas, un taçón, una taça blanca, que pesó todo siete marcos e çinco onças e medias" 209.

Alguna información se ofrece sobre el precio y el alquiler de la vivienda. Una deuda de 150 maravedís se reclaman por el alquiler de unas casas ${ }^{210}$, aunque no sabemos de cuánto tiempo; como tampoco sabemos si el precio de una casa en el barrio de San Miguel se corresponde con los 300 maravedís por la que es embargada y a los que asciende la deuda de su propietaria ${ }^{211}$, pero que puestas en almoneda únicamente alcanzaron 100 maravedís ${ }^{212}$. En la calle de la Alcacería se alquilaron unas casas por dos años al precio de 9 florines de oro, a pagar a plazos de "cuatro en cuatro meses" ${ }^{213}$, y en Moya se dan unas casas en censo enfitéutico ${ }^{214}$ por el mismo precio y condiciones que el alquiler de Cuenca. A estas es-

207 ก. 7

208 ก. 43.

209 Sobre los términos que aparecen para definir algunos trabajos de orfebrería podemos hacer los siguientes comentarios: Los «botones a manera de morillas" sin duda se refiere a que tenian una forma ligeramente convexa, asemejando setas, quizá con decoración imitando las celdillas de los panales de colmenas. Cfr. J. Corominas, J. A. PAscual, Diccionario crítico etimológico, IV, p. 147. El término "Cuchiareta", labor en la que están trabajadas dos tazas, podría estar definiendo un adorno de "gallones" con la factura semejante a la copa del cáliz que describe A. LópEz-YARTO ELIZALDE, La orfebrería del siglo XVl, p. 380, n. 286: “copa acampanada con subcopa de gallones... que hemos visto en la orfebrería de Cuenca desde el primer renacimiento". En otras descripciones se refieren a estos adornos como de "lengüetas", tal como observamos en la base del cáliz fechado hacia 1500 comentado por F. J. MoNTalvo Martin, con el n. 239 del catálogo de la exposición Ysabel, la Reina Católica. Una mirada desde la Catedral Primada, Toledo, 2005, pp. 514-515. Que conozcamos, no es hasta principios del siglo XVI cuando aparece el término comentado en la documentación para referirse a cálices "acucharados", y es en E. ARNÁEZ, Orfebreria religiosa en la provincia de Segovia hasta 1700, Madrid, 1983, p. 86. De la labor "Sevillana" en que están labrados algunos botones no he encontrado nada concreto, aunque sin duda está haciendo referencia a una forma de trabajar de los orfebres de la ciudad hispalense de la que, al parecer, no ha quedado testimonio escrito. Sobre la orfebreria sevillana puede verse J. M. CRUZ VALDOVINOS, Cinco siglos de platería sevillana, Sevilla, 1992, donde en la p. XXV dice que «la platería de esta ciudad no empieza a resultar bien conocida para nosotros en la actualidad si no es en el siglo $x \mathrm{~V}$, en especial a partir de los Reyes Católicos"

210 ก. 9.

211 n. 20.

$212 \mathrm{nn} .22,30$.

213 n. 24

214 ก. 4 . 
cuetas noticias para la historia del urbanismo conquense ${ }^{215}$, podemos añadir las menciones de algunas casas, con sus límites y aledaños, en otras dos calles, la del Alcázar ${ }^{216}$ y la del Peso ${ }^{217}$, además de la Puerta del Canto ${ }^{218}$ y de la Plaza de la Picota ${ }^{219}$, donde son voceados los pregones.

A través de todo ello hemos podido observar un entramado social de oficios y profesiones del sector primario y secundario, agricultores, alfayates, cardadores, carpinteros, carraleros, carreteros, cirujanos, "escrividor» 220 , escuderos, físicos, jubeteros, juboneros, madereros, molineros, olleros, pastores, pellejeros, perailes, plateros, recueros, sanadores, sastres, tejedores, tenderos, tintoreros, zapateros; oficios de la adminitración, urbana y regia, alguaciles, pregoneros, escribanos, juez, alcalde del rey, arrendadores y recaudadores de la alcabala de la carne, de las carnicerías, de la "çerondaja», de las salinas, del pan de cahices, del portazgo de los sesmos; regidores, corregidor, Alcalde de la Casa de la Moneda, tesorero y depositario del Rey.

Vemos que algunos personajes frecuentan con asiduidad la oficina de nuestro escribano, casi siempre de forma protagonista, para escriturar negocios que dan la impresión de mover en torno a sus personas intereses y clientelismo que, sin duda, les proporcionarían saneados beneficios; entre ellos, Alfonso González de Guadalajara, Álvar Garcia del Castillo, y, sobre todos, Alfonso Álvarez de Toledo ${ }^{221}$. Es curiosa la mínima presencia de miembros de la Iglesia entre los muchos personajes que circulan por nuestro registro, si exceptuamos a los frailes que forman parte de la comunidad de franciscanos que, en representación de su convento, solicitan la presencia de nuestro escribano para que dé testimonio fidedigno del acuerdo ${ }^{222}$ a que han llegado con un tercero, y de los que podemos destacar su alta cualificación académica: doctores y maestros en Lógica y Teología. Después únicamente el capellán de la iglesia de san Pedro de Moya que actúa en representación de su hermano, canónigo de Mondoñedo y secretario del obispo Álvaro de Isorna ${ }^{223}$; el capellán de la iglesia de Mohorte, testamentario en un pleito que pende ante el Juez eclesiástico ${ }^{224}$, y un tal «don Pedro, Arcediano de

215 A este respecto, puede verse, J. M. SANCHEZ BENITO, El espacio urbano de Cuenca en el siglo XV, Cuenca, 1997.

${ }^{216}$ n. 72. Donde solían vivir los zapateros.

217 ก. 41

218 n. 41 .

$219 \mathrm{nn} .14,15,18,22,30$.

220 El oficio de «escrevidor» que dice tener Lázaro Díaz, bien podría referirse a que presta sus servicios de amanuense en alguna de las oficinas notariales de Cuenca, como encargado de la tarea de poner por escrito los documentos que los «escribano públicos» fedataban. La existencia, por otra parte lógica, de estos profesionales de la pluma, está recogida en J. Bono HuERTA, Historia del Derecho, I. 2, pp. 336-338.

221 Puede verse: J. A. JARA FuENTES, Concejo, poder y élites. La clase dominante de Cuenca en el siglo xv, Madrid, 2000. Y. Guerrero Navarrete, J. M. Sanchez Benito, Cuenca en la Baja Edad Media, pp. 133- 154. Y. Guerrero NavarRete, "Economía y poder en Cuenca en el siglo xV», La economía conquense en perspectiva histórica, Cuenca, 2000, pp. 72-95.

222 n. 2.

223 ก. 4.

224 ก. 51 
Alarcón», deudor de Álvar García del Castillo ${ }^{225}$. Ningún miembro de otras creencias religiosas aparece entre los clientes de Simón Fernández.

\section{REGESTO DEL REGISTRO 226}

1.

1423, mayo, 7, viernes.

Recaudo de Lope Sánchez de Cuenca, notario, vecino de Cuenca, como marido de la hija de Juan Sánchez de Andújar, difunto, para la percepción de la parte que corresponde a su mujer de la mitad de la renta de las salinas del Obispado de Cuenca en este año, de las que habia sido arrendador el dicho Juan Sánchez de Andújar. (f. 1r.)

2.

1423, mayo, 11, martes. En el convento de san Fracisco.

Testimonio notarial a petición de fray Fernando de Oviedo, maestro en Teología, fray Juan de Villalpando, vicario, fray Luis de sevilla, doctor, fray Pedro de la Plaza, maestro de Lógica, y fray Juan de Cuenca, de la Orden de san Francisco, como representantes de su convento, de haber aceptado la petición de enterramiento en una capilla de la iglesia de Catalina Rodríguez, mujer de García Ruiz de Alarcón, solicitada por su madre, Juana Rodríguez de Huércemes, a condición de que ésta cumpla el testamento de su marido, Diego García de Jarava, y edifique la capilla donde han de ser enterrados su marido y su hija. (ff. 1r.-v.)

3.

1423, mayo, 23.

Procuración de Juan Ruiz, platero, vecino de Moya, a favor de Gonzalo Fernández, platero, vecino de Cuenca, para que le represente en todos los asuntos y negocios que requieran su atención. (f. 2r.)

4.

1423, mayo, 23.

Censo enfiteútico de Gómez Aries de Villamayor, capelián de la iglesia de san Pedro de Moya, en nombre de Gonzalo Yáñez, su hermano, canónigo de Mon-

225 ก. 56.

${ }_{226}$ Ante la imposibilidad material de publicar el Registro hemos optado por realizar el regesto de cada uno de sus asientos, a los que hemos acompañado, por creer que seria de utilidad, de un índice de los nombres de todos los personajes que, con mayor o menor protagonismo, aparecen a lo largo de sus folios. 
doñedo y secretario de don Álvaro de Isorna, obispo de Cuenca, de quien presentó carta de poder (Toledo, 5 de enero de 1423), a Juan Ruiz, platero, vecino de Moya, de unas casas en la villa de Moya, a condición de recibir anualmente cuatro florines y medio de oro, de peso, ley y cuño de Aragón. (ff. 2r.-3v.)

5.

1423, mayo, 24.

Recaudo puesto por García Alfonso de Soria y Juan González, escudero, vecinos de Cuenca, por el que anulan el compromiso de arbitraje que anteriormente habían realizado en la persona de Sancho García de Molina. (f. $3 \mathrm{v}$.)

6.

1423, mayo, 31.

Recaudo de Alfonso Martínez de Graos, hijo de Juan Martínez de Graos, tintorero, vecino de Cuenca, por el que se obligó a pagar el día de santa María de agosto, a Fernando Manuel de Belmonte, vecino de Cuenca, diez florines de oro de peso, ley y cuño de Aragón, por la compra de un rocín de color alazán. (f. $4 \mathrm{r}$.)

7.

1423, junio, 3.

Contrato de aprendiz entre Diego López, platero, hijo de Adán López, platero, vecino de Cuenca, y Fernando, hijo de Lope Rodríguez de Cuenca, vecino de Sevilla, para que le enseñe el oficio de la plateria, estipulando las condiciones que se han de observar por ambas partes. (ff.4r-v.)

8.

1423, junio, 3.

Requerimiento de Alfonso García de Moya, zapatero, vecino de Cuenca, arrendador de la renta de pan de cahices de Malpesa el año 1421, a Pedro, vecino de Malpesa, para que le pague seis almudes de trigo que le adeuda de dicha renta, de lo contrario le tendría que pagar 50 maravedís por cada fanega. (f. $4 \mathrm{v}$.)

9.

1423, junio, 3.

Carta de poder de Álvaro de Albalate, escudero de Teresa de Luna, a favor de Juan Fernández de Teruel, vecino de Cuenca, para que pueda cobrar de Juan Sánchez de Zahorejas, vecino de Cuenca, 150 maravedís que le adeuda por el alquiler de unas casas. (ff. $4 \mathrm{v}-5 \mathrm{r}$.) 
10.

1423, junio, 4.

Carta de dote de Juana García, hija de Fernando Garcia de Villar del Saz, bachiller, de 300 florines de oro, de la ley y cuño de Aragón, a Pedro Martínez del Castillo, vecino de Cuenca, escribano del rey. (f. 5r.)

11.

1423, junio, 4.

Carta de pago y finiquito otorgada por Fernando Sánchez de San Clemente a Alfonso González de Uclés, tendero, vecino de Cuenca, de las deudas que hasta hoy le debía. (f. 5v.)

12.

1423, junio, 4.

Carta de obligación de Alfonso González de Uclés, de devolver a Fernando Sánchez los 340 maravedís de la moneda usual que le había prestado. (f. 5v.)

13.

1423, junio, 4.

Carta de poder de Pedro Martínez del Castillo, escribano del rey, a favor de Fernando Manuel, vecino de Cuenca, para que demande y cobre a Alfonso Fernández de Cañaveras, vecino de Cuenca, 352 maravedís y cinco ducados que había prestado a Pedro Fernández de Reillo, difunto, y del que había salido como avalista. (ff. 5v-6r.)

14.

1423, junio, 5, sábado.

Pregón de Juan López, pregonero público de Cuenca, por mandato de García Gutiérrez de León, alguacil por Gonzalo García de Madrid, bachiller en leyes y Corregidor de Cuenca, de la almoneda de unos balandranes pardillos de paño de Cuenca y forrados de pana blanca, propiedad de Pedro Fernández de Cuenca. Alfonso López, tejedor de lienzos, vecino de Cuenca, pujó 80 maravedís. Es el primer pregón. (f. 6r.)

15.

1423, junio, 10.

Pregón de Juan López. Es el segundo pregón de la almoneda anterior. Se mantuvo la misma puja. (f. 6 r.) 
16.

1423, junio, 10, jueves.

Carta de pago de Juan de Almorox, escudero de Diego López de Ayala, de los 13. 864 maravedis que le habian sido librados por Alfonso Fernández de Castro, Garcia del Castillo y Montesino Manuel, vecinos de Cuenca, como arrendadores de la alcabala de la cerondaja el pasado año, por Fernando Sánchez de Moya, arrendador del partido de Moya. (f. 6v.)

17.

1423, junio, 10, jueves.

Carta de obligación de Sancho Sánchez de Guadalajara, jubonero, vecino de Cuenca, a favor de Alfonso Álvarez de Toledo y de Juan Fernández de Valera, como su procurador, de pagarle 225 maravedís de la moneda usual en Castilla, que le debia por la compra de una arroba de algodón. (f. 6v.)

18.

1423, junio, 14, lunes.

Pregón de Juan Rodríguez, pregonero, por mandato de García Gutiérrez, alguacil, de la almoneda de unos balandranes de paño pardillo de Cuenca, aforrados de pana blanca, que son de Pedro Fernández de Cuenca. No se subió la puja. Es el tercer pregón. (f. $6 \mathrm{v}$.)

19.

1423, junio, 14, lunes.

Requerimiento de [García Gutiérrez], alguacil de Cuenca, a Pedro Fernández de Cuenca, para que mejore la puja o pague la deuda de los balandranes, de lo contrario se hará remate de ellos. (f. 7 r.)

20.

1423, junio, 14, lunes.

Cumplimiento por García Gutiérrez, alguacil de Cuenca, de un mandamiento del Corregidor, para que haga entrega de los bienes de Juana López, mujer que fue de Martín López de Ygerna, por cuantía de 300 maravedís que debía a María, moza de Juan Álvarez de Herriega. (f. 7r.)

21.

1423, junio, 15, martes.

Carta de obligación de Gil Jiménez de Ervias, vecino de Torralba, a favor de Álvaro Álvarez de Toledo, Alcalde de la Casa de la Moneda, y de Juan Fer- 
nández de Valera, escribano del rey, en su nombre, de entregarle 550 maravedís de la moneda usual, por la compra de cinco varas de paño de Ipres turquesado. (f. 7r.)

22.

1423, junio, 15, martes.

Pregón de Juan López, pregonero, por mandato de [García Gutiérrez], alguacil, de la almoneda de unas casas de Juana López, mujer de Martín López de Ygerna. Pujó 100 maravedís Juan Fernández, pregonero. Es el primer pregón. (f. $7 \mathrm{v}$.)

23.

1423, junio, 15, martes.

Carta de obligación de Pascual Sánchez de Alcocer, vecino de Cuenca, a favor de Ángel García de Molina, vecino de Cuenca, de 630 maravedis de la moneda usual, por otros "altantos" que le había prestado amigablemente. (f. $7 \mathrm{v}$.)

24.

1423, junio, 16, miércoles.

Carta de obligación de Fernando López Rosillo, zapatero, vecino de Cuenca, a favor de Gabriel López Jiménez, vecino de Cuenca, como tutor de Álvaro y de Catalina, hijos de Juan López Jiménez, su hermano, de nueve florines de oro, de peso, ley y cuño de Aragón, que le debía por el alquiler de unas casas en la calle de la Alcacería. ( $f$. $7 \mathrm{v}$.)

25.

1423, junio, 16, miércoles.

Carta de obligación de Juan del Castillo y Juan de Ávila, jubeteros, habitantes en Cuenca, de devolver a García Alfonso de Soria, vecino de Cuenca, los 420 maravedís de la moneda usual que les había prestado. (ff. $7 \mathrm{v}-8 \mathrm{r}$.)

26.

1423, junio, 17, jueves.

Carta de poder de Álvar García del Castillo, vecino de Cuenca, a favor de Gonzalo Sánchez, alfayate, vecino de Cuenca, especialmente para que pueda demandar y cobrar de Ruy Fernández Fidalgo, vecino de Cuenca, 230 maravedís y tres «forcas» de cebollas que le debe por carta de obligación. (f. 8r.) 
27.

1423, junio, 17, jueves.

Carta de poder de Luis Sánchez de Torralba, sastre, vecino de Cuenca, a favor de Sancho Fernández de Huesca, vecino de Cuenca, para que le represente en todos los asuntos que fuere menester. (f. 8r.)

28.

1423, junio, 17, jueves.

Carta de poder de García Martínez del Castillo, maderero, vecino de Cuenca, a favor de Pedro Martínez del Castillo y de Fernando Manuel, vecinos de Cuenca, para que le representen en todos los asuntos que fuere menester. (f. $8 \mathrm{v}$.)

29.

1423, junio, 23, miércoles.

Juramento de Miguel Sánchez del Villar, Miguel Sánchez y Vicente Ferrero, vecinos de Torralba, de pagar a Fernando Sánchez de Moya, recaudador de los pedidos y alcabalas de Torralba, cierta cantidad de maravedís que restan de pagar del año pasado. (f. $8 \mathrm{v}$.)

30.

1423, junio, 25.

Pregón de Fernando Fernández, pregonero, por mandato de García Gutierrez, alguacil, de la almoneda de las casas de Martín López de Ygerna. Es el segundo pregón. (f. 8v.)

31.

1423, junio, 25, viernes.

Carta de poder de Teresa de Luna a favor de Pedro López del Monte, escribano público de Huete, para que se le puedan librar por los contadores mayores del Rey los 20 . 000 maravedís y 400 fanegas de pan que tenía concedidos anualmente. (f. 9r.)

32.

1423, junio, 25, viernes.

Carta de poder de Teresa de Luna a favor de Pedro López del Monte, para que se le puedan librar los 11.000 maravedis de que le había hecho merced el Rey, para pago de la costa del tiempo que estuvo en la Corte el año pasado. (f. 9r.) 
33.

1423, junio, 25, viernes.

Carta de obligación de Diego Martínez Vaquero, hijo de Juan Martínez Vaquero, vecino de Cuenca, deudor, y Gonzalo García de Moya, zapatero, su fiador, a favor de Álvar Garcia del Castillo, vecino de Cuenca, de 700 maravedís de la moneda usual que le había prestado. (f. 9r.)

34

1423, julio, 12.

Petición de tutoría y curaduría de Fernando, hijo de Gonzalo González de Cañizares, para sus hermanos, menores de edad, ante Gonzalo García de Madrid, bachiller en leyes, Alcalde de la Corte del Rey y su Corregidor en Cuenca, porque su madre, Blanca González, había vuelto a contraer matrimonio. Fueron dados en tutela a Pedro Gómez de Cuenca, su tío. (f. 9v.)

35.

1423, julio, 14.

Contrato y obligación de Pedro Gómez de Cuenca y Juan de Teruel, vecinos de Cuenca, para cobrar las deudas que eran debidas a Gonzalo González de Cañizares, difunto, de las que son herederos Blanca González, su mujer e hijos, menores de edad, y percibir por ello el la décima parte de todo lo cobrado. Entre las deudas señaladas están 2. 200 maravedís que debe el Concejo de Enguídanos, pero se exceptúan las deudas que pudieran tener Juan Martínez de la Parra y otras personas por «prendas». (f. 10r-v.)

36.

1423, julio, 16, viernes.

Carta de obligación de Juan de Fontanas, peraile, vecino de Cuenca, a favor de Alfonso Álvarez de Toledo, Alcalde de la Casa de la Moneda, y de Juan Fernández de Valera en su nombre, escribano del rey, vecino de Cuenca, para adabar 28 paños "mercaderos de los que se hacen" en Cuenca y que ya le había sido abonado. (f. 10v.)

37.

1423, julio, 16, viernes.

Carta de obligación de Juan de Fontanas, peraile, [vecino de Cuenca], a favor de Álvar García, para devolverle los 335 maravedís de la moneda usual que le había prestado amigablemente. (f. 10v.) 
38.

1423, julio, 16, viernes.

Recaudo (contrato) entre Mateo Enrique, cirujano, vecino de Castillo de Garcimuñoz, y Juan Fernández de Valera, escribano del rey, vecino de Cuenca, para curarle una llaga que tiene en la ingle, por lo cual recibirá 60 florines de oro, de la ley y cuño de Aragón. (f. 10v.)

39.

1423, julio, 16, viernes.

Carta de poder de Blanca González, mujer de Gonzalo González de Cañizares, difunto, a favor de Juan Fernández de Teruel y de Pedro Gómez de Cuenca, vecinos de Cuenca, para que puedan recibir los bienes que se adeudaban a su marido. (ff. 11r-v.)

40.

1423, julio, 16, viernes.

Carta de obligación de Alfonso Sánchez de Toledo, ollero, a favor de Álvar García del Castillo, vecinos de Cuenca, para devolverle los 96 maravedís y medio que le habia prestado. (f. 11v.)

41.

1423, julio, 22.

Contrato de desposorios entre Alfonso Yáñez de Huélamo, vecino de Cuenca, padre de Juana Sánchez, viuda de Fernando Sánchez de Villalba, y Juan Fernández de Cañizares, vecino de Cuenca. Se especifica la dote que el padre entrega a la novia, y de no realizarse el matrimonio la parte que rompa el contrato pagará 1.000 florines de oro, de la ley y cuño de Aragón. (f. 12r.)

42.

1423, julio, 22.

Testimonio de Simón Fernández, escribano, a petición de Juan López, pregonero público de Cuenca, de haber dejado una carta de recudimiento por mandato de Gonzalo Garcia, corregidor, y de Fernando Sánchez de Moya, regidor, en la casa de Alonso Fernández de Alcocer, tintorero, vecino de Cuenca, para que fuera fiel de la alcabala de la carne de la ciudad de Cuenca en el año presente. En ausencia se le pregonó por fiel de la alcabala. (f. 12v.) 
43.

1423, julio, 23.

Recaudo de Fernando Sánchez de Moya, recaudador de la alcabala del partido de Cuenca, reconociendo haber recibido de Teresa Sánchez, mujer de Juan Sánchez de Bazo, difunto, 6. 032 maravedís y cinco ducados del pago de la cuarta parte de la renta de la alcabala de la carne de la ciudad de Cuenca del año pasado, del que fue arrendador su marido. (f. 12v.)

44.

1423, julio, 23.

Recaudo de Jaime Gilabert, vecino de Cuenca, recaudador del portazgo del sesmo de la Sierra el año pasado, y recaudador el presente por Juan Díaz de Alcocer, vecino de Cuenca, obligándose a entregarle todo lo que recogiese del portazgo. (f. 13r.)

45.

1423, julio, 23.

Obligación de Juan Sánchez de la Cuesta y Miguel Sánchez Andrés, vecinos de Beteta, en nombre del Concejo de dicho lugar, de pagar a Fernando Sánchez de Moya y a Diego García de Molina, vecinos de Cuenca, 100 florines de oro, de peso, ley y cuño de Aragón, por cuanto se los habian prestado anteriormente. (ff. 13r-v.)

46.

1423, agosto, 1.

Carta de poder de Diego García de Molina, vecino de Cuenca, a favor de Pedro Martínez del Castillo, escribano del rey y vecino de Cuenca, para que en su nombre cobre de Pascual Sánchez de Molina, vecino de Castillo de Garcimuñoz, 5. 000 maravedís, más los réditos, y saldar asi la deuda que hay entre ambos. (f. 13v.)

47.

1423, agosto, 3.

Contrato entre Juan Sánchez de Cañaveras y Miguel, hijo de don Adán, vecinos de Cuenca, y Pedro Fernández de Cañaveras, Pedro Fernández de Zahorejas, regidores de Cuenca, Pedro Sánchez de Palomera, Miguel Sánchez de Valdecabras, Gómez García de Villalvilla, Juan Álvarez de Herriega, vecinos de Cuencá, para que guarden las viñas del pago de Cabeza Molina, término de Cuenca, hasta el tiempo de la vendimia, por el que recibirán tres maravedís por cada aranzada. (ff. 13v-14r.) 
48.

1423, agosto, 7, sábado.

Petición de sentencia ante Juan López de la Puebla, bachiller en leyes y Alcalde de Cuenca por Gonzalo García, corregidor, de Lope Sánchez de Teruel y Miguel Sánchez Cardero, vecinos de Cuenca, del pleito que entre ambos pasó ante Álvar Alfonso de Montemayor, sobre demanda de 75 maravedís. (ff. 14r.-14v.)

49.

1423, agosto, 12.

Juramento de Andrés López de Huélamo, recuero, veino de Cuenca, de transportar hasta Cuenca desde Tragacete y Las Majadas 20 fanegas y tres celemines de trigo que restaban de las 133 fanegas que se habia comprometido a traer para Álvar García del Castillo, vecino de Cuenca. (f. 14v.)

50.

1423, agosto, 12 .

Testímonio de Lázaro Díaz, "escrevidor», vecino de Cuenca, a petición de Alfonso González de Guadalajara, vecino de Moya, de deberle 408 maravedís una vez ajustadas las cuentas de la venta de cuatro cahices de pan, por mitades de trigo y cebada, a 20 maravedís la fanega, a cuenta de 16 florines de oro que costó un mulo que le había comprado para el Comendador de Santiago de Cuenca, y restados 72 maravedís que costó el porte del pan desde Ranera a Moya. (f. 14V.)

51.

1423, agosto, 14 .

Compromiso de elección de jueces árbitros entre Juan de Portillo, vecino de Cuenca, como procurador de Diego Pérez, capellán de Mohorte, testamentario de Juan Sánchez de la Torre, difunto, y Gonzalo Núñez de la Muela, vecino de Cuenca, en nombre de Constanza Pérez, su madre, en el pleito que pende entre ambos ante el juez de la Iglesia de Cuenca, por 1.500 maravedís de la venta de lana. (f. 15r.)

52.

1423, agosto, 14.

Obligación de Lope de Cifuentes, sastre, vecino de Cuenca, de pagar a Alfonso Álvarez de Toledo, Alcalde Mayor de la Casa de la Moneda de Cuenca, 600 maravedís de la moneda usual de dos blancas un maravedí, por ciertos paños berbi verdes de Flandes que le había comprado. (f. 15r.) 
53.

1423, agosto, 14 .

Compromiso de elección de jueces árbitros entre Alfonso Fernández del Castillo y Pedro López de Escamilla, en nombre de Catalina Fernández, su hija y mujer de Nuño Fernandez, difunto, vecinos de Cuenca, en el pleito que les enfrentaba por el alquiler de unas casas. (f. 15v.)

54.

1423, agosto, 17 .

Carta de poder de Juan González de Alcalá, vasallo del Rey, a favor de Gonzalo Núñez de la Muela, vecinos de Cuenca, para que pueda recaudar y recibir de Fernando Sánchez de Alcaraz, vecino de Cuenca, 14. 000 maravedís que en él le había librado Alfonso González de Guadalajara, recaudador del Obispado de Cuenca, del pedido y moneda del año 1421, más 1.500 maravedis y cuatro alfombras de almulque que le debe. (f. 15v.)

55.

1423, agosto, 17.

Compromiso de elección de jueces árbitros entre Alfonso Fernández de Alcaraz, el Mozo, vecino de Cuenca, arrendador de las tercias de la parte que pertenecen al Rey en el sesmo de Altarejos el año pasado, y Benito Martínez, vecino de Valera de Abajo, como procurador de los herederos de Andrés Martínez, su hermano, tercero lego que fue de dicho lugar. (f. 16r.)

56.

1423, agosto, 17.

Carta de pago otorgada por Pedro de Castro, criado y procurador de don $\mathrm{Pe}$ dro, arcediano de Alarcón, a Álvar García del Castillo, vecino de Cuenca, de 38 florines de oro que faltaban de pagar de algunos rediezmos del fruto del año pasado que habían arrendado Diego López del Castillo y Pedro Fernández de Castro, vecinos de Castillo de Garcimuñoz. (f. 16r.)

57.

1423, agosto, 17.

Carta de pago otorgada por Juan Bendicho a Juan Fernández de Valera, hijo de Juan Fernández de Valera, vecinos de Cuenca, de 400 maravedís que le había entregado en cumplimiento de una sentencia arbitral, y que restaban de la compra de una mula. (f. 16v.) 
58.

1423, agosto, 18 .

Carta de obligación de María Sánchez, mujer de Gil Martínez de las Zomas, difunto, a favor de Francisco Martínez de Cañete, vecinos de Cuenca, de un «panno blanco en filaza ordido, estabre e trama, bueno e de buena lana e filaza areado", de un lienzo que le debía como heredera de su madre. (f. 16v)

59.

1423, agosto, 18.

Recaudo entre Alfonso González de Guadalajara y Gutierre González de Guadalajara, escribano del rey, y Alfonso González de Écija, vecino de Uclés, sobre ciertas fianzas, (incompleto). (f. 16v.)

60.

1423, agosto, 19.

Contrato entre Diego de Jérica, hijo de Antón Fernández de Jérica, y García Gutiérrez de Guadalajara, escribano del rey, por un año a partir del presente día. Las cláusulas de contrato son las siguientes: Diego de Jérica se compromete a servirle sin romper el contrato, bajo pena de una multa de cuatro maravedís, a cambio de la manutención y de 1.000 maravedís de la moneda usual.(f. 17r.)

61.

1423, agosto, 19.

Carta de poder de Juan Fernández de Valera, hijo de Juan Fernández de Valera, a favor de Álvar García del Castillo, vecinos de Cuenca, para que le pueda representar ante cualquier autoridad para resolver sus negocios. (f. 17r.)

62.

1423, agosto, 24.

Carta de poder de Luis Sánchez de Valera, vecino de Belmonte, a favor de Lope Sánchez de Cuenca, notario y vecino de Cuenca, para que le pueda representar a la hora de resolver sus negocios. (f. 17r.)

63.

1423, agosto, 25.

Contrato entre Alfonso Álvarez y Gil Martínez de Tondos, vecino de Torralba, y María Sánchez, su mujer, para criar y amamantar por espacio de 18 meses a Mencía, su hija, recibiendo 50 maravedís mensuales. (f. 17.) 
64.

1423, agosto, 29.

Carta de obligación de Sancho Sánchez de Arcas, vecino de Cuenca, a favor de Álvaro Paez de Écija, vecino de Cuenca, de devolverle 390 maravedís de la moneda usual que le había prestado amigablemente. (f. 17v.)

65.

1423, septiembre, 3 .

Juramento de Juan Jiménez de Vara de Rey, vecino de Honrubia, de pagar a Alfonso Álvarez de Toledo 180 maravedís más un almud del pan de las tercias reales del año de 1418. (f. 17v.)

66.

1423, agosto, 31.

Carta de poder de Alfonso Álvarez de Toledo a favor de Juan Fernández de Teruel, vecinos de Cuenca, para que pueda administrar todos sus bienes. (f. 18r.)

67.

1423, septiembre, 15. Huete.

Juramento de Lope Álvarez de Molina, vecino de Huete, de pagar a Alfonso Álvarez de Toledo, vecino de Cuenca, representante de Alfonso González de Guadalajara, recaudador mayor del partido de Huete por el Rey, 10. 000 maravedís puestos en Toledo, en poder de Nuño López de Saldaña, tesorero y depositario del Rey, en cuenta de lo que se racaudó del pedido del Obispado de Cuenca el pasado año. (f. 18r.)

68.

1423, septiembre, 13. Huete.

Recaudo de Pedro Gómez de León, escribano del rey y vecino de Uclés, para servir el oficio de la escribanía de las rentas de las villas y lugares que la Orden de Santiago tiene en el Obispado de Cuenca, con Belinchón e Hinojosos del Marquesado, en nombre de Alfonso Álvarez, cobrando diez maravedís de cada 1.000 maravedis. (f. 18v.)

69.

1423, septiembre, 13. Huete.

Recaudo de Roy Gutiérrez, escribano público en Huete, para servir el oficio de la escribania de las villas de Huete y su tierra en nombre de Alfonso Álvarez. (f. 18v.) 
70.

1423, septiembre, 16. Huete.

Racuado de Lope Álvarez de Molina de pagar a Alfonso Álvarez de Toledo, en nombre de los herederos de Juan Álvarez de Molina, vecinos de Huete, 1. $281 \mathrm{ma}$ ravedís en cuenta de lo recaudado del pedido de Huete y sus villas y lugares del pasado año, puestos en Cuenca. (ff. 18v-19r.)

71.

1423, septiembre, 16. Huete.

Recaudo de Alfonso González de Guadalajara, recaudador mayor del partido de Huete por el Rey, de pagar a Alfonso Álvarez 10. 000 maravedís del pedido de Huete el pasado año, en nombre de Nuño López de Saldaña, tesorero y depositario del Rey. (f. 19r.)

72.

1423, septiembre, 21. Cuenca.

Testimonio de la toma de posesión de unas casas por Alfonso Álvarez de Toledo, alcalde, en la calle del Alcazar de Cuenca, donde vivían Gutierre Díaz de Sandoval y Catalina Díaz, su mujer. (ff. 19r-v.)

73.

1423, septiembre, 22. Fuentes.

Obligación de Miguel Sánchez de la Mota, vecino de Fuentes, de pagar a Álvar Garcia del Castillo y a Juan Álvarez de Montemayor, arrendadores de la renta de la alcabala del sesmo de Arcas, del presente año, 270 maravedis de la moneda usual, que les debe por su atajo de la alcabala con las carnicerías de Fuentes. (f. 19v.)

74.

1423, septiembre, 22. Fuentes.

Obligación de Pedro Sánchez Izquierdo, vecino de Fuentes, de pagar a Álvar García del Castillo y a Juan Álvarez de Montemayor, arrendadores de la renta de la alcabala del sesmo de Arcas, 80 maravedís por atajo de su alcabala. (f. 19v.)

75.

1423, septiembre, 22. Fuentes.

Requerimiento de Alfonso Álvarez de Toledo, Alcalde Mayor de la Casa de la Moneda de Cuenca, a Pedro Martínez, carretero, vecino de Fuentes, para que le pague el pan de la renta que le debe. (f. 20r.) 
76.

1423, septiembre, 22. Fuentes.

Requerimiento de Pedro Martínez, carretero, a Pascual Gómez, carretero, vecinos de Fuentes, para que le pague nueve cahíces de pan mediados de trigo y cebada. (f. 20r.)

77.

1423, septiembre, 22. Fuentes.

Poder de Miguel Sánchez, hijo de Gonzalo Gill, Gonzalo Martínez de Pedrosa, Pedro López de Torres y Juan Sánchez de Fuentes, vecinos de Fuentes, a favor de Juan Fernández de Teruel, vecino de Cuenca, para que presente ante el Concejo de Cuenca solicitud para arrendar la hierba del término de dicho lugar. (f. 20r.)

78.

1450, junio, 16. Cuenca.

Petición de Aldonza Rodríguez, mujer de Juan Rodríguez de la Flor, vecino de Cuenca, ante Juan Núñez de la Muela, alcalde ordinario de Cuenca por el Rey, y en presencia de Lope González de León, escribano público de esta ciudad, para que se le conceda licencia para poder nombrar procuradores en ausencia de su marido.

\section{APÉNDICE}

1423, julio, 3, sábado. Cuenca.

Acta municipal del nombramiento de Álvar Alfonso y Juan González como escribanos públicos de la ciudad de Cuenca, y posterior juramento de los nombrados.

A.- A. M. C. Leg. 187, Exp. 2, ff. 14 r- 15 v. Precortesana. Tinta ocre.

En la çibdat de Cuenca, sábado, tres días del mes de jullio, anno del nasçimiento del nuestro salvador Jhesucristo de mill e quatroçientos e veynte e tres annos. Estando juntados en las casas de los ayuntamientos de la dicha çibdat el concejo e corregidor, cavalleros, escuderos, ofiçiales e omnes buenos de la dicha çibdat a concejo, a boz de pregón, segunt que lo han de uso e de costunbre de se juntar; e estando y presentes, en el dicho conçejo, el honrrado e descreto Gonçalo Garçía de Madrit, bachiller en leyes, alcallde de nuestro sennor el rey en la su corte e su corregidor en la dicha çibdat e su tierra, e Diego Garçia de Montoya, bachiller en decretos, teniente logar de guarda por el noble cavallero Diego Furtado de Mendoça, montero mayor del dicho sennor rey e su guarda mayor de la dicha çibdat de Cuenca e su tierra, Sancho de Jarava, e Diego Sánchez Donnes, e Pero Ferrández de Cannaveras, e Gómez Garçía de Molina, e Ferrand Alfonso de Guadal- 
fajara, regidores de la dicha çibdat, e Matheo Sánchez de Xávaga, procurador síndico de la dicha çibdat, e Diego Ferrández de Molina, mayordomo e receptor de los maravedís de propios e rentas de la dicha çibdat [e] de su tierra, e otros pieça de gente, quantos y quisieron venir al dicho conçejo. E en presençia de mí, Juan López de Buenache, escrivano e notario público de nuestro sennor el rey en la su corte e en todos los sus regnos, e escrivano público del conçejo de la dicha çibdat, e de los testigos yuso escriptos, el dicho conçejo en concordia, e todos a una voluntad, dixeron que por quanto por mi, el dicho escrivano, ellos avían antes de agora críado por sus escribanos públicos de la dicha çibdat a Álvar Alfonso de Montemayor e a Juan González de Briuega, escrivano del dicho sennor rey, vezinos de la dicha çibdat, que presentes estavan, en lugar //(f. 14 r.) e por muerte e subçesión de Luys González de la Sierra e de Juan Sánchez de Molina, finados que Dios perdone, escrivanos públicos que fueron desta dicha çibdat, que mandavan e mandaron a mí, el dicho Juan López, escrivano, que asiente en el libro e registro del dicho conçejo que yo tengo de la dicha çibdat, la dicha criaçión de los dichos escrivanos, segunt e por la forma que están asentadas las otras creaçiones de los otros escrivanos públicos que son en la dicha çibdat, faziendo en ella mençión en commo el dicho conçejo e ofiçiales en concordia crió por sus escrivanos públicos de la dicha çibdat.

E que a mayor abondamiento, por quanto la voluntad del dicho conçejo estonçes fue e agora es que los dichos Álvar Alfonso e Juan González, e cada uno dellos, sean escrivanos públicos de la dicha çibdat, en lugar de los dichos Luys González e Juan Sánchez, e que usen e gozen de los dichos ofiçios, que ha mayor abondamiento agora nuevamente el dicho conçejo, en concordia e a vuena voluntad, dixieron que criavan e criaron a los dichos Álvar Alfonso e Juan González por sus escrivanos públicos de la dicha çibdat e les fazian nueva provisión e mercet del dicho ofiçio, ratificando e aviendo por firme e valedera la dicha primera çitaçión que les fizieron, e todos los otros actos e escripturas que antellos e ante cada uno dellos han pasado, e que mandavan e mandaron a mí, el dicho Juan López, escrivano, que ge lo diese asi a cada uno dellos por testimonio.

E los dichos Álvar Alfonso e Juan González, que presente estavan, dixieron que ellos, al tienpo e sazón de la dicha primera criaçión e provisión que del dicho ofiçio les fue fecha, que la avían aceptado e usado del dicho ofiçio de escrivanos e que aún agora eso mesmo, que nuevamente açeptan e açeptaron la dicha merçet e ofiçio, e pidiéron // (f. 14 v.) lo por testimonio.

E luego, el dicho conçejo resçibieron juramento de los susodichos Álvar Alfonso y Juan González e de cada uno de ellos, sobre la sennal de la Cruz e las palabras de los sanctos Evangelios que con sus propias manos derechas tanieron; so virtud del qual dixieron que ellos e cada uno dellos, bien e leal e verdaderamente usarán del dicho ofiçio de escrivanía, e que farán las escripturas e cartas que ante ellos e ante cada uno dellos pasaren lealmente e su alongamiento, e que non catarán y amor nin desamor, nin miedo nin verguença nin pliego nin don que les den nin prometan; e sobresto todo, que guardarán poridat de nuestro senno el rey e su sennorío, e su cuerpo e su muger e sus fijos, e todas las cosas que a él pertenesçen, 
segunt aquello que ellos han de fazer.

E otro sí, que guardarán el provecho común e honrra del dicho conçejo en quanto ellos pudieren e sopieren.

E otro si, que ellos e cada uno dellos estarán sienpre prestos e aparejados para fazer todo lo que el conçejo e ofiçiales desta çibdat tienen ordenado e ordenaren e mandaren, guardando el serviçio del dicho sennor rey.

E otro si, que yrán así commo escrivanos, e cada uno de ellos, a todos e qualesquier logares e actos quel dicho conçejo e los dichos ofiçiales en su nonvre mandaren, e que non demandarán nin resçebirán alguno dellos más nin allende de veynte e çinco maravedís cada día, segunt que es costunbre.

E otro sí, que por las escripturas que qualquier dellos toviere e oviere de façer que sean de la dicha çibdat e para el conçejo della que non levarán dineros nin presçio alguno, salvo solamente lo que costare el escriviente que escriviere las tales escripturas, e que se abengan con el tal escriviente los regidores, e que el escrivano dellos que signe las tales escripturas e non lieve dineros.

E fecho el dicho juramento, e echada sobrellos la confusión // (f. 15 r.) dél, cada uno dellos respondió si juro.

E fecha la dicha jura, el dicho conçejo dixieron que les davan liçençia e actoridat, segunt que primeramente ge la avían dado, e que interponían e interpusieron su decreto, aquel que de derecho devían, para usar del dicho ofiçio de que antes le era fecha provisión, e de la nueva criaçión e provisión que les agora avían fecho.

De lo qual todo, los dichos Álvar Alfonso e Juan González, pidieron a mí, el dicho Johan López, testimonio signado, cada uno de los quales el suyo, e más para guarda del su derecho.

Testigos: (el resto en blanco). // (f. 15 v.).

\section{INDICE ONOMÁSTICO DEL REGISTRO Y APÉNDICE 227}

Adán, padre de Miguel, vecino de Cuenca: 47 .

Adán López, platero, padre de Diego López, platero, vecino de Cuenca, testigo: 7.

Alfonso, menor de edad, hermano de Fernando, hijo de Garcia González de Cañizares: 34, 35.

227 Se han ordenando las entradas por los nombres y no por los apellidos, unificados según la forma actual castellana. Aunque creemos que no son muchos los casos, preferimos aumentar el número de entradas antes de omitir algún nombre; esto sucede cuando en el documento aparecen personas con el mismo nombre y primer apellido, pero sin el topónimo que da lugar al segundo apellido y nos encontramos con una persona distinta, aunque todo nos hace pensar que se trata del mismo sujeto. Procuramos acompañar el nombre y apellidos de alguna palabra o conjunto de palabras que determinan la condición, calidad, etc, del titular en el documento. La cifra o cifras que figuran detrás de cada persona hacen referencia al número de orden del asiento dentro del registro, que nosotros les hemos dado para mejor operatividad en el estudio realizado; de igual forma la abreviatura Ap., que acompaña a algunos de ellos, hace referencia al Apéndice. 
Alfonso Álvarez, padre de Mencia: 63.

Alfonso Álvarez, vecino de Cuenca, testigo: 54,74

Alfonso Álvarez, tio de Pedro de Alcalá, vecino de Cuenca: 29, 34

Alfonso Álvarez, acreedor de Alfonso González de Guadalajara, recaudador mayor del partido de Huete: 71.

- acreedor de Juan Álvarez de Molina: 70.

- amo de Juan Sánchez del Zarzoso y de Luis de Guadalajara, testigos: 65.

- poderdante de Álvaro de Luna, escribano de las rentas del obispado de Cuenca: 68.

- poderdante de Roy Gutiérrez, escribano público en Huete: 69.

- recaudador del pedido de Huete el año 1422: 70.

- vecino de Cuenca, testigo: 73, 74.

Alfonso Álvarez de Toledo, acreedor de Juan Jiménez de Vara de Rey: 65.

- acreedor de Lope Álvarez de Molina, vecino de Huete: 67, 70.

- acreedor de Lope de Cifuentes, sastre: 52.

- acreedor de Sancho Sánchez de Guadalajara, jubonero: 17.

- Alcalde de la Casa de la Moneda: 21, 72.

- Alcalde de la Casa de la Moneda de Cuenca, acreedor de Juan de Fontanas, peraile: 36.

- Alcalde Mayor de la Casa de la Moneda de Cuenca por el rey, acreedor de Pedro Martínez, carretero: 76.

- poderdante de Juan Fernández de Teruel, vecino de Cuenca: 66.

- vecino de Cuenca, testigo: 1, 77.

Alfonso Díaz de León, zapatero, casas de herederos de: 72.

Alfonso de Cetina, hijo de Diego Fernández de Cetina, vecino de Cuenca, testigo: 6 .

Alfonso Fernández, hijo del juez de Valdecabras, vecino de Cuenca, testigo: 19.

Alfonso Fernández de Alcaraz, amo de Juan de Alcalá: 24.

Alfonso Fernández de Alcaraz, el Mozo, vecino de Cuenca, arrendador de las tercias del rey en el sesmo de Altarejos del año de 1422: 55.

Alfonso Fernández de Alcaraz, el Viejo, vecino de Cuenca, testigo: 5.

Alfonso Fernández de Alcocer, tiniorero, vecino de Cuenca, fiel de la alcabala de la carne: 42.

Alfonso Fernández de Cañaveras, vecino de Cuenca, deudor de Pedro Martínez del Castillo: 13.

Alfonso Fernández de Castillo, vecino de Cuenca, arrendador de la alcabala de la cerondaja de Cuenca: 16.

- casero de Catalina Fernández: 53.

Alfonso Fernández de Castro, vecino de Cuenca, arrendador de la alcabala de la cerondaja: 16.

- fiador de Pedro Gómez de Cuenca, testigo: 34 .

- testigo: 49, 55.

Alfonso García de Moya, zapatero, vecino de Cuenca, arrendador de la renta de pan de cahices de Malpesa: 8.

- testigo: 23.

Alfonso García de Pardiñas, escribano del rey, vecino de Cuenca, testigo: 34.

Alfonso García del Quintanar, vecino de Cuenca, testigo: 40.

Alfonso Gómez, zapatero, vecino de Cuenca, testigo: 28.

Alfonso González de Écija, deudor de Alfonso González de Guadalajara: 59.

Alfonso González de Guadalajara, vecino de Moya, acreedor de Gutierre González y de Alfonso González de Écija: 59.

- acreedor de Lázaro Díaz, "escrevidor»: 50.

- amo de Diego de Valdeolivas: 59.

— amo de Esteban de Valdeolivas: 70.

- amo de Gutierre González de Guadalajara, escribano del rey y escribano de Valdeolivas: 70 . 
- recaudador del obispado de Cuenca del pedido y monedas del año 1421: 54.

- recaudador mayor del partido de Huete por el rey: 67.

- recaudador mayor del partido de Huete por el rey, deudor de Alfonso Álvarez: 71.

Alfonso González de Uclés, tendero, vecino de Cuenca, deudor de Fernando Sánchez de San Clemente: 11, 12.

Alfonso López, escribano, casas de: 41.

Alfonso López, tejedor de lienzos, vecino de Cuenca: 14.

Alfonso Martinez de Graos, hijo de Juan Martínez de Graos, tintorero, vecino de Cuenca, deudor de Fernando Manuel de Belmonte: 6.

Alfonso Martínez de Valverde, vecino de Cuenca, testigo: 9.

Alfonso Paez de Écija, vecino de Cuenca, acreedor de Sancho Sánchez de Arcas: 64.

Alfonso Ruiz, vecino de Cuenca, juez árbitro: 51.

Alfonso Sánchez de Alcalá, sastre, vecino de Cuenca, testigo: 4.

Alfonso Sánchez de Olivares, vecino del Castillo, carta de poder de: 65.

Alfonso Sánchez de Toledo, ollero, vecino de Cuenca, deudor de Álvar García del Castillo: 40.

Alfonso Yáñez de Huélamo, vecino de Cuenca, padre de Juana Sánchez: 41.

Álvar Alfonso de Montemayor, escribano público de Cuenca, testigo: 3,6 .

- escribano: 48.

- escribano del rey, vecino de Cuenca: Ap.

Álvar García, acreedor de Juan de Fontanas, peraile: 37.

Álvar Garcia de Molina, vecino de Cuenca, testigo: 41.

Álvar García del Castillo, vecino de Cuenca, acreedor de Alfonso Sánchez de Toledo: 40.

- acreedor de Andrés López de Huélamo: 49.

- acreedor de Diego Martínez Vaquero: 33.

- acreedor de Juan de Fontanas, peraile: 37.

- apoderado de Juan Fernández de Valera, hijo de Juan Fernández de Valera: 61.

- arrendador de la alcabala del sesmo de Arcas, acreedor de Miguel Sánchez de la Mota: 73.

- arrendador de la alcabala del sesmo de Arcas, acreedor de Pedro Sánchez Izquierdo: 74.

- deudor de Pedro, arcediano de Alarcón: 56.

- poderdante de Gonzalo Sánchez, alfayate, vecino de Cuenca: 26.

- testigo: $17,24,25,36,38,57$.

Álvar González de Huerta, escribano del rey, vecino de Cuenca, juez árbitro: 55.

Álvaro, menor de edad, hijo de Juan López Jiménez: 24.

Álvaro de Albalate, escudero de Teresa de Luna: 9.

Álvaro de Luna, escribano de las rentas del obispado de Cuenca: 68.

Álvaro de Isorna, obispo de Cuenca: 4.

Álvar Sánchez de Teruel, vecino de Cuenca, testigo: 59.

Andrés Martínez, hermano de Alfonso Fenández de Alcaraz, el Mozo, tercero del lugar de Valera de Abajo: 55.

Andrés López de Huélamo, recuero, vecino de Cuenca: 49.

Ángel Garcia de Molina, vecino de Cuenca, acreedor de Pascual Sánchez de Alcocer: 23.

- testigo: 41.

Antón Martínez, vecino de Cuenca, testigo: 48.

Antón Martínez de Priego, escribano, vecino de Cuenca, testigo: 45.

Arias de León, hombre de Gonzalo Gómez de Herrera, testigo: 60.

Bartolomé Sánchez de Huete, tintorero, vecino de Cuenca, testigo: 8.

Benito de Guadalajara, criado de Alfonso Álvarez de Toledo, testigo: 65.

Blanca González, madre de Fernando, mujer de Gonzalo González de Cañizares: 34, 35, 39.

Catalina, menor de edad, hija de Juan López Jiménez: 24.

Catalina Díaz, mujer de Gutierre Díaz de Sandoval, vecina de Cuenca: 72, 73. 
Catalina Fernández, hija de Pedro López de Escamilla, mujer de Nuño Fernández, inquilina de Alfonso Fernández del Castillo: 53.

Catalina Rodriguez, difunta, hija de Diego García de Jarava y de Juana Rodríguez de Guérmeces, y mujer de García Ruiz de Alarcón: 2.

Constanza Pérez, madre de Gonzalo Núñez de la Muela: 51.

Diego de Jérica, hijo de Antón Fernández de Jérica, asalariado de Garcia Gutiérrez de Guadalajara: 60 .

Diego de Molina, criado de Alfonso González de Guadalajara, testigo: 68.

Diego de Valdeolivas, criado de Alfonso González de Guadalajara, vecino de Cuenca, testigo: 59 .

Diego Fernández de Chumilla, majuelo de: 41.

Diego Fernández de Molina, vecino de Cuenca, testigo: 47.

Diego Fernández de Molina, el Cezo, vecino de Cuenca, mayordomo y receptor de los maravedís de propios y rentas de Cuenca y su tierra: Ap.

- testigo: 2, 27, 38, 63, 72 .

- tio de Fernando, vecino de Cuenca, aprendiz de platero: 7 .

Diego García de Jarava, difunto, marido de Juana Rodríguez de Guérmeces: 2.

Diego Garcia de Molina, vecino de Cuenca, acreedor de Juan Sánchez de la Cuesta y de Miguel Sánchez Andrés: 45.

- juez árbitro: 51.

- poderdante de Pedro Martínez del Castillo, acreedor de Pascual Sánchez de Molina: 46.

Diego Garcia de Montoya, bachiller en decretos, teniente lugar de guarda mayor por Diego Hurtado de Mendoza: Ap.

Diego Hurtado de Mendoza, montero mayor del rey y guarda mayor de Cuenca y su tierra: Ap.

Diego López de Ayala, poderdante de Juan de Almorox: 16.

Diego López del Castillo, vecino de Castillo de Garcimuñoz, deudor de Pedro, arcediano de Alarcón: 56.

Diego López, platero, hijo de Adán López, platero, vecino de Cuenca: 7.

Diego Martínez Vaquero, hijo de Juan Martínez Vaquero, el Viejo, vecino de Cuenca, deudor de Álvar Garcia del Castillo: 33.

Diego Núñez de la Muela, vecino de Cuenca, testigo: 59.

Diego Pérez, capellán en Mohorte, testamentario de Juan Sánchez de la Torre, difunto, poderdante de Juan de Portilla: 51.

Diego Rodriguez de Baeza, testigo: $67,69$.

Diego Sánchez Dónez, regidor de Cuenca: Ap.

Domingo Fernández, clérigo de San Gil, vecino de Cuenca, testígo: 1.

Domingo Fernández de Lozoya, vecino de Cuenca, testigo: 41.

Domingo Garcia, capellán que fue de la iglesia de san Pedro de Moya: 4.

Esteban de Valdeolivas, criado de Alfonso González de Guadalajara, testigo: 70.

Esteban Rodríguez de Torrelaguna, criado de Alfonso Álvarez, testigo: 68 .

Fernando, hijo de García González de Cañizares, mayor de catorce años, vecino de Cuenca: $34,35$.

Fernando, hijo de Lope Alfonso de Cuenca, vecino de Sevilla, aprendiz de platero: 7.

Fernando Alfonso de Guadalajara, regidor de Cuenca: Ap.

- vecino de Cuenca, testigo: 1.

Fernando Álvarez, jubonero, vecino de Huete, testigo: 67,68 .

Fernando de Belmonte, acreedor de Pedro Fernández de Cuenca: 14.

- vecino de Cuenca, testigo: 55.

Fernando de Oviedo, fray, maestro en Teología: 2.

Fernando Fernández, pregonero de Cuenca: 30.

Fernando Fernández, testigo: 38.

Fernando Fernández de Mariana, vecino de Cuenca, testigo: 52. 
Fernando García de Alarcón, notario, vecino de Cuenca, juez árbitro: 55.

Fernando García de Molina, testigo, vecino de Cuenca: 3.

Fernando García de Villar del Saz, bachiller, padre de Juana Garcia: 10.

Fernando González de Ávila, escribano del rey, vecino de Cuenca, testigo: 5.

Fernando González de Huerta, vecino de Cuenca, testigo: 42.

Fernando López de Beamud, vecino de Cuenca, testigo: 25.

Fernando López Rosillo, zapatero, vecino de Cuenca, deudor de Gabriel López Jiménez: 24.

Fernando Manuel, vecino de Cuenca, apoderado de García Martínez del Castillo: 28.

- testigo: 47.

Fernando Manuel, apoderado de Pedro Martínez del Castillo:13.

Fernando Manuel de Belmonte, vecino de Cuenca, acreedor de Alfonso Martínez de Graos: 6 .

Fernando Martínez: 70.

Fernando Martínez, arador, padre de Lope Jubonero: 10.

Fernando Martínez, el Rufo, vecino de Cuenca, testigo: 53.

Fernando Martínez de Cañete, casas de: 24.

- vecino de Cuenca, testigo: 55.

Fernando Ruiz de Albalate, vecino de Cuenca, criado de Teresa de Luna, testigo: 31.

- testigo: 30, 66 .

Fernando Sánchez, clérigo de epistola, notario público, testigo: 4.

Fernando Sánchez, notario: 56.

Fernando Sánchez de Alcaraz, vecino de Cuenca, deudor de Juan González de Alcalá, vasallo del rey: 54 .

Fernando Sánchez de Huete, vecino de Cuenca, testigo. 35.

Fernando Sánchez de Moya, acreedor de Juan Sánchez de la Cuesta y de Miguel Sánchez Andrés: 45.

- arrendador del partido de Moya: 16.

- fiador de Pedro Gómez de Cuenca: 34.

- recaudador del pedido y alcabala del concejo de Torralba: 29.

- recaudador de la alcabala del partido de Cuenca: $42,43$.

- vecino de Cuenca, testigo: $35,44,62,63,73,74,75,77$.

Fernando Sánchez de San Clemente, acreedor de Alfonso González de Uclés: 11, 12.

Fernando Sánchez de Sevilla, vecino de Cuenca, testigo: 8.

Fernando Sánchez de Villalba, difunto, marido de Juana Sánchez : 41.

Francisco Martínez de Ballesteros, vecino de Cuenca, testigo: 42.

Francisco Martínez de Cuenca, acreedor de Maria Sánchez, mujer de Gil Martínez de las Zomas, difunto: 58 .

Francisco Núñez de Toledo, recaudador del pedido del obispado de Cuenca del año 1422: 67,71 .

Francisco Sánchez de Bólliga, tejedor, vecino de Cuenca: 17.

Gabriel López Jimenez, vecino de Cuenca, tutor de Álvaro y Catalina, hijos de Juan López Jiménez: 24.

Gabriel Alfonso, vecino de Huete, cobrador de lo que se adeuda a Blanca González: 35. - testigo: 34.

Gabriel Sánchez Castiel, vecino de Cuenca, testigo: 58.

García Alfonso de Soria, vecino de Cuenca, acreedor de Juan del Castillo y de Juan de Ávila:

25.

- acreedor de Juan González, escudero: 5.

- testigo: 24, 58.

Garcia Álvarez, amo de Pedro González: 50.

García del Castillo, vecino de Cuenca, arrendador de la alcabala de la cerondaja: 16.

García Gutiérrez de Guadalajara, escribano del rey, amo de Diego de Jérica: 60.

García Gutiérrez de León, alguacil de Cuenca por Gonzalo García de Madrid: 14, 18, 19, 20 , 30. 
Garcia Martínez del Castillo, maderero, vecino de Cuenca, poderdante de Pedro Martínez del Castillo y de Fernando Manuel: 28.

Garcia Ruiz de Alarcón, marido de Catalina Rodríguez: 2.

García Sánchez del Castillo, vecino de Cuenca, arrendador de la alcabala de la cerondaja de Cuenca: 16.

Gil Fernández de Briones, casas de: 41.

Gil Jiménez de Ervias, vecino de Torralba, deudor de Alfonso Álvarez de Toledo, alcalde de la casa de la moneda de Cuenca: 21.

Gil Martínez de Chinchilla, arador, vecino de Cuenca, testigo:17.

Gil Martinez de las Zomas, difunto, marido de María Sánchez: 58.

Gil Martínez de Tondos, vecino de Torralba, marido de María Sánchez: 63.

Gil Sanchez de Valdemeca, tejedor, vecino de Cuenca, testigo: 10.

Gómez Garcia de Villalvilla, propietario de viñas, vecino de Cuenca: 47.

Gómez Arias de Villamayor, procurador de Gonzalo Yáñez, su hermano: 4.

Gómez Garcia de Molina, regidor de Cuenca: Ap.

Gómez García de la Muela, vecino de Cuenca, testigo: 7.

Gómez García, el Viejo, vecino de Cuenca, testigo: 46.

Gonzalo de Santa María, hijo de Juan Sánchez de Santa María, vecino de Cuenca, testigo: $16,20$.

Gonzalo Fernández, platero, vecino de Cuenca, procurador de Juan Ruiz: 3.

- testigo: 4.

Gonzalo Fernández de Soria, vecino de Cuenca, testigo: 30.

Gonzalo Fernández de Valenzana, vecino de Cuenca, testigo: 8.

Gonzalo Fernández del Castillo, sanador, vecino de Cuenca, testigo: 45.

Gonzalo Garcia de Madrid, bachiller en leyes, alcalde en la corte del rey y corregidor de Cuenca y su tierra: 34 .

- corregidor de Cuenca y su tierra por el rey: 14, 42, Ap.

- corregidor de Cuenca: 48.

Gonzalo García de Moya, zapatero, fiador de Diego Martínez Vaquero, vecino de Cuenca: 33.

Gonzalo Gil, padre de Miguel Sánchez: 77.

Gonzalo Gómez de Herrera, testigo: 60.

Gonzalo González de Frías, vecino de Cuenca, testigo: 38.

Gonzalo González de Cañizares, difunto, marido de Blanca González: 34, 35, 39.

Gonzalo Garcia del Castillo, zapatero, casas de: 72.

Gonzalo González Francés, vecino de Cuenca, testigo: 38, 43, 44.

Gonzalo Martínez, vecino de Cuenca, testigo: 42.

Gonzalo Martínez de Pedrosa, vecino de Fuentes, poderdante de Juan Fernández de Teruel:

77.

- testigo: 76.

Gonzalo Núñez de la Muela, vecino de Cuenca, procurador de Constanza Pérez, su madre: 51.

- procurador de Juan González de Alcalá, vasallo del rey: 54.

Gonzalo Rodríguez de Pareja, sastre, vecino de Cuenca, testigo: 53.

Gonzalo Rodríguez de la Flor, vecino de Cuenca, testigo: 13, 15, 35.

Gonzalo Sánchez, alfayate, vecino de Cuenca, apoderado de Álvar Garcia del Castillo: 26.

Gonzalo Sánchez de Moya, vecino de Villaescusa de Haro, testigo: 62.

Gonzalo Yáñez, canónigo de Mondoñedo, secretario del obispo de Cuenca, capellán de San

Pedro de Moya: 4.

Gregorio Vázquez, vecino de Cuenca, testigo: 33.

Gutierre Díaz de Sandoval, marido de Catalina Díaz, vecino de Cuenca: 72.

Gutierre González de Guadalajara, escribano del rey, testigo: 67, 69, 71.

- escribano del rey y escribano de Valdeolivas, criado de Alfonso González de Guadalajara: 70 . 
Íñigo, cardador, vecino de Cuenca, testigo: 20, 27.

iñigo de Alsedo, cardador, vecino de Cuenca, testigo: 33.

Jaime Gilabert, vecino de Cuenca, recaudador del portazgo del sesmo de la Sierra: 44 .

Juan Alfonso, arrendador de la renta de las alcabalas de los lugares del sesmo de Arcas: 74 .

Juan Álvarez de Herriega, vecino de Cuenca, amo de Juana: 20.

- propietario de viñas: 47.

- testigo: 1.

Juan Álvarez de Molina, vecino de Huete, deudor de Alfonso Álvarez : 70.

- recaudador del pedido de Huete: 71.

Juan Álvarez de Montemayor, arrendador de la alcabala del sesmo de Arcas, acreedor de Miguel Sánchez de la Mota: 73.

- arrendador de la alcabala del sesmo de Arcas, acreedor de Pedro Sánchez Izquierdo: 74.

Juan Álvarez del Castillo, vecino de Cuenca, testigo: 40.

Juan Bendicho, vecino de Cuenca, acreedor de Juan Fernández de Valera, hijo de Juan Fernández de Valera: 57.

Juan de Alcalá, criado de Alfonso Fernández de Alcaraz, vecino de Cuenca, testigo: 24.

Juan de Almorox, escudero de Diego López de Ayala: 16.

Juan de Ávila, jubetero, habitante en Cuenca, deudor de García Alfonso de Soria: 25.

Juan de Cuenca, fray, del convento de san Francisco de Cuenca: 2.

Juan de Fontanas, peraile, vecino de Cuenca, deudor de Alfonso Álvarez de Toledo: 36.

- deudor de Álvar García: 37.

Juan de Portillo, vecino de Cuenca, testigo: 9, 52.

- procurador de Diego Pérez, capellán: 51.

Juan de Toro, criado de Juan González de Alcalá, vecino de Cuenca, testigo: 40.

Juan de Valmaseda, criado de Gonzalo Fernández, vecino de Cuenca, testigo: 4.

Juan de Villalpando, fray, vicario del convento de san Francisco de Cuenca: 2.

Juan del Castillo, jubetero, habitante en Cuenca, deudor de Garcia Alfonso de Soria: 25.

Juan Díaz de Alcocer, vecino de Cuenca, arrendador del portazgo del sesmo de la Sierra:

44.

- testigo: 7, 43, 51, 52.

Juan Fernández de Cañizares, vecino de Cuenca, prometido de Juana Sánchez: 41.

- testigo: 13.

Juan Fernández de Cuéllar, vecino de Cuenca, testigo: 42.

Juan Fernández de Teruel, vecino de Cuenca, procurador de Alfonso y Juana, menores edad: 35.

- procurador de Alfonso Álvarez de Toledo: 66.

- procurador de Álvaro de Albalate, vecino de Cuenca: 9.

- procurador de Blanca González, 39.

- procurador de varios vecinos de Fuentes: 77.

- testigo: $23,72,73,74,75$.

Juan Fernández de Toledo, clérigo de Cadahalso, criado del maestrescuela de Cuenca, testigo: 4.

Juan Fernández de Valera, vecino de Cuenca, escribano del rey: 21, 38

- escribano del rey, procurador de Alfonso Álvarez de Toledo: 36.

- hijo de Juan Fernández de Valera, vecino de Cuenca, testigo: 54, 56.

- deudor de Juan Bendicho: 57.

- poderdante de Álvar García del Castillo, vecino de Cuenca: 61.

- procurador de Alfonso Álvarez de Toledo: 17.

Juan Fernández de Valera, vecino de Cuenca, padre de Juan Fernández de Valera : 54, 56, 57. Juan Garcia, vecino de Cuenca, hijo de Yanez García, pellejero, testigo: 3, 14.

Juan González, clérigo de Segovia, notario apostólico: 4.

Juan González, escudero, vecino de Cuenca, deudor de García Alfonso de Soria: 5. 
Juan González de Alcalá, amo de Juan de Toro: 40.

- vasallo del rey, vecino de Cuenca, poderdante de Gonzalo Núñez de la Muela: 54. Juan González de Brihuega, vecino de Cuenca, escribano del rey: Ap.

Juan Jiménez de Vara de rey, vecino de Honrubia, deudor de Alfonso Álvarez de Toledo: 65. Juan López, clérigo de San Juan, vecino de Cuenca, testigo: 29.

Juan López, pellejero, vecino de Cuenca, testigo: 20.

Juan López, pregonero público de Cuenca: 14, 22, 42.

Juan López Chico, vecino de Cuenca, testigo: 64.

Juan López de Buenache, escribano público y del concejo de Cuenca: nota de apertura.

- escribano y notario público del rey en su corte y en todos sus reino y escribano público del concejo de Cuenca: Ap.

Juan López de Madrid, tejedor, vecino de Cuenca, testigo: 11.

Juan López de la Puebla, bachiller en leyes, alcalde de Cuenca por el corregidor Gonzalo

Garcia: 48.

Juan Luis, recuero, vecino de Cuenca, testigo: 36.

Juan Martínez de Alcocer, vecino de Cuenca, testigo: 11.

Juan Martínez de Arcas, vecino de Cuenca, peraile, testigo: 14.

Juan Martínez de Arrancacepas, casa que fue de: 41.

Juan Martínez de Valhermoso, vecino de Cuenca, testigo: 53.

Juan Martínez de la Parra, deudor de García González de Cañizares: 35.

Juan Martínez de las Zomas, vecino de Cuenca, testigo: 21, 22, 47.

Juan Martínez de Roa, vecino de Cuenca, testigo: 37.

Juan Martínez Vaquero, el Viejo, padre de Diego Martínez Vaquero: 33.

Juan Rodríguez, juez árbitro: 53.

- pregonero de Cuenca: 15, 18, 22.

Juan Rodríguez, sanador, vecino de Cuenca, testigo: 18.

Juan Ruiz, platero, vecino de Moya: 3, 4.

Juan Sánchez Bazo, difunto, marido de Teresa Sánchez, recaudador de las alcabalas de la carne de la ciudad de Cuenca: 43.

Juan Sánchez Bendicho, vecino de Cuenca, testigo: 46, 56.

Juan Sánchez Cerraquén, vecino de Cuenca, testigo: 26,64 .

Juan Sánchez de Andújar, difunto, arrendador de las rentas de las salinas del obispado, sue-

gro de Lope Sánchez de Cuenca: 1.

Juan Sánchez de Cañaveras, viñadero, vecino de Cuenca: 47.

Juan Sánchez de Fuentes, vecino de Fuentes, poderdante de Juan Fernández de Teruel: 77.

Juan Sánchez de Molina, difunto, escribano de Cuenca: Ap.

Juan Sánchez de Palacio, casa de: $\mathbf{4 1 .}$

- escribano público de Cuenca, testigo: 21.

Juan Sánchez de Sarrión, escribano, vecino de Cuenca, testigo: 23, 42.

Juan Sánchez de Santa María, padre de Gonzalo de Santa María: 16.

Juan Sánchez de Teruel, haza de: 41.

Juan Sánchez de Tragacete, peraile, vecino de Cuenca, testigo: 25, 28.

Juan Sánchez de Tregeto, vecino de Cuenca, testigo: 2.

- peraile, vecino de Cuenca, testigo: 61 .

Juan Sánchez de Valdecabras, peraile, vecino de Cuenca, testigo: 29.

Juan Sánchez de Zahorejas, vecino de Cuenca, deudor de Teresa de Luna: 9.

Juan Sánchez del Zarzoso, vecino de Cuenca, criado de Alfonso Álvarez, testigo: 65.

- testigo: $54,63,66,76,77$.

Juan Sánchez de la Cuesta, vecino de Beteta, deudor de Fernando Sánchez de Moya: 45. Juan Sánchez de la Torre, difunto: 51.

Juan Sánchez Moreno, vecino de Cuenca, testigo: 18.

Juana, menor de edad, hermana de Fernando, hijos de Garcia González de Cañizares: 34,

35. 
Juana García, mujer de Pedro Martínez del Castillo, hija de Fernando García de Villar del

Saz: 10.

Juana López, mujer de Martín López de ..., difunto: 20, 22.

Juana Rodríguez de Guérmeces, mujer de Diego García de Jarava, difunto: 2.

Juana Sánchez, hija de Alfonso Yáñez, viuda de Fernando Sánchez de Villalba: 41.

Lázaro Díaz, "escrividor», vecino de Cuenca, deudor de Alfonso González de Guadalajara:

50.

Lope Álvarez de Molina, vecino de Huete, deudor de Alfonso Álvarez de Toledo: 67, 70.

- testigo: 69,71 .

Lope de Cifuentes, sastre, vecino de Cuenca, deudor de Alfonso Álvarez de Toledo: 52.

Lope de Villar del Saz, criado de Alfonso Álvarez, testigo: 68.

Lope Fernández de Écija, vecino de Cuenca, testigo: 61.

Lope Fernández de Huete, vecino de Cuenca, testigo: 13, 15.

Lope Garcia de Andújar, casas de: 24.

Lope González Calahorrano, vecino de Huete, cobrador de lo que se adeuda a Blanca

González: 35.

- testigo: 34

Lope, jubonero, hijo de Fernando Martinez, arador, vecino de Cuenca, testigo: 10.

Lope López de Madrid, padre de Pedro de Madrid: 16.

Lope Martínez de la Torre, padre de Juana Rodriguez de Guérmeces: 2.

Lope Rodríguez de Antezana, testigo: 2.

Lope Sánchez de Alarcón, vecino de Cuenca, testigo: 61.

Lope Sánchez de Brihuega, majuelo de: 41.

Lope Sánchez de Cuenca, vecino de Cuenca, apoderado de Luis Sánchez de Valera: 62.

- notario: 1.

- notario, juez árbitro: 57.

- notario, testigo: 26.

- notario apostólico, testigo: 6 .

Lope Sánchez de Teruel, vecino de Cuenca, acreedor de Miguel Sánchez Cardero: 48.

Lope Sánchez del Castillo, tundidor, vecino de Cuenca, testigo: 4.

Luis González de la Sierra, difunto, escribano público de Cuenca: Ap.

Luis de Guadalajara, vecino de Cuenca, testigo: 54.

- criado de Alfonso Álvarez, testigo: 65.

Luis Sánchez de Torralba, sastre, vecino de Cuenca, poderdante de Sancho Fernández de Huesca: 27.

Luis Sánchez de Valera, vecino de Belmonte, poderdante de Lope Sánchez de Cuenca: 62.

Luis de Sevilla, fray, doctor: 2.

Maria, moza de Juan Álvarez de Herriega: 20.

María Sánchez, mujer de Gil Martínez de las Zomas, difunto, vecina de Cuenca, deudora de

Francisco Martinez de Cuenca: 58.

Maria Sánchez, mujer de Gil Martínez de Tondos: 63.

Martín Alfonso de Vara de Rey, criado de Alfonso Páez, vecino de Cuenca, testigo: 64.

Martín López de Ygerna, difunto, marido de Juana López: 20, 22, 30.

Mateo Enrique, cirujano, vecino de Castillo de Garcimuñoz: 38.

Mateo Pedro, físico, vecino de Huete, testigo: 70, 71.

Mateo Sánchez de Jávaga, vecino de Cuenca, procurador síndico de Cuenca: Ap.

- testigo: 58.

Mencía, hija de Alfonso Álvarez: 63.

Miguel, hijo de Adán, viñadero, vecino de Cuenca: 47.

Miguel García de Molina, vecino de Cuenca, testigo: 50.

Miguel López de Bólliga, notario, vecino de Cuenca, testigo: 19.

Miguel Martínez, molinero, vecino de Cuenca, testigo: 14, 46.

Miguel Martínez de Mira, casas de herederos de: 4. 
Miguel Ruiz, escribano, vecino de Cuenca, testigo: 22.

Miguel Sánchez, hijo de Gonzalo Gil, vecino de Fuentes, poderdante de Juan Fernández de Teruel: 77.

Miguel Sánchez Andrés, deudor de Fernando Sánchez de Moya: 45.

Miguel Sánchez Cardero, vecino de Cuenca, deudor de Lope Sánchez de Teruel: 48.

Miguel Sánchez Mendaño, vecino de Cuenca, testigo: 16, 45, 49, 50, 57.

Miguel Sánchez de Valdecabras, vecino de Cuenca, propietario de viñas: 47.

- testigo: 18.

Miguel Sánchez de Vicente Ferrero, vecino de Torralba, deudor de Fernando Sánchez de Moya: 29.

Miguel Sánchez del Villar, vecino de Torralba, deudor de Fernando Sánchez de Moya: 29.

Miguel Sánchez de la Guarda, corralejo de: 41.

Miguel Sánchez de la Mota, vecino de Fuentes, deudor de Álvar García del Castillo y de Juan Álvarez de Montemayor: 73.

Montesino Manuel, vecino de Cuenca, arrendador de la alcabala de la cerondaja de Cuenca: 16.

Nicolás López, escribano, vecino de Cuenca, testigo: 27.

Nuño Fernández, marido que fue de Catalina Fernández: 53.

Nuño López de Saldaña, tesorero y depositario del rey: 67,71 .

Pascual Gómez, carretero, vecino de Fuentes, deudor de Pedro Martínez: 77.

Pascual López de Villar del Saz, vecino de Valera de Suso, acreedor de Juan Díaz: 44.

- testigo: 66.

Pascual Sánchez de Alcocer, vecino de Cuenca, deudor de Ángel Garcia de Molina: 23.

- recuero, testigo: 36.

Pascual Sánchez de Molina, vecino de Castillo de Garcimuñoz, deudor de Diego García de Molina: 46.

Pedro, arcediano de Alcalá, poderdante de Pedro de Castro: 56.

Pedro, tejedor, criado de Francisco Sánchez de Bólliga, vecino de Cuenca, testigo: 17.

Pedro, vecino de Malpesa, deudor de Alfonso García de Moya: 8.

Pedro de Alcalá, vecino de Cuenca, testigo: 26.

Pedro de Alcalá, sobrino de Alfonso Álvarez, vecino de Cuenca, testigo: 29, 34.

Pedro de Castro, criado y procurador de Pedro, arcediano de Alcalá: 56.

Pedro de la Plaza, fray, maestro de Lógica en el convento de san Francisco de Cuenca: 2.

Pedro de Madrid, vecino de Cuenca, hijo de Lope López de Madrid, testigo: 16.

Pedro Fernández, vecino de Castillo de Garcimuñoz, deudor de Pedro, arcediano de Alarcón: 56.

Pedro Fernández de Calahorra, caballero de maza del rey, vecino de Cuenca, testigo: 72 .

Pedro Fernández de Cañaveras, regidor de Cuenca: 47, Ap.

- vecino de Cuenca, testigo: 15.

Pedro Fernández de Cuenca, deudor de Fernando de Belmonte: 14, 15, 18, 19.

- testigo: 42, 48.

Pedro Fernández de Pareja, zapatero, vecino de Cuenca, testigo: 39.

Pedro Fernández de Villora, criado de Teresa de Luna, vecino de Cuenca, testigo: 9, 39.

Pedro Fernández de Reillo, difunto, deudor de Pedro Martínez del Castillo: 13.

Pedro Fernández de Uclés, vecino de Cuenca, testigo: 45.

Pedro Fernández de Zahorejas, regidor de Cuenca: 47.

Pedro Garcia de Gomara, carralero, vecino de Cuenca, testigo: 39.

Pedro Gómez de Cuenca, vecino de Cuenca, curador y tutor de Alfonso y Juana, menores de edad: 34.

- procurador de Alfonso y Juana, menores de edad: 35.

- procurador de Blanca González: 39.

- testigo: $28,43,44,51$.

Pedro González, criado de Garcia Álvarez, vecino de Cuenca, testigo: 50. 
Pedro González de Córdoba, testigo: 60.

Pedro González de León, vecino de Uclés, escribano del rey: 68.

Pedro López de Priego, vecino de Cuenca, testigo: 48.

Pedro López de Escamilla, vecino de Cuenca, padre de Catalina Fernández: 53.

Pedro López de Torres, vecino de Huete, poderdante de Juan Fernández de Teruel: 77.

Pedro López del Monte, escribano público en Huete, apoderado de Teresa de Luna: 31, 32.

Pedro Martínez, carretero, vecino de Fuentes, acreedor de Pascual Gómez: 76.

- deudor de Alfonso Álvarez de Toledo: 75.

Pedro Martínez del Castillo, marido de Juana García, vecino de Cuenca, escribano del rey: 10.

- escribano del rey, apoderado de Diego Garcia de Molina: 46.

- escribano del rey, testigo: $11,30,45,56$.

- poderdante de Fernando Manuel, vecino de Cuenca: 13.

Pedro Martínez del Castillo, vecino de Cuenca, apoderado de García Martínez del Castillo: 28.

Pedro Sánchez de Palomera, tintorero, vecino de Cuenca, propietario de viñas: 47.

- testigo: 21, 22.

Pedro Sánchez de Santa María, vecino de Cuenca, testigo: 31.

Pedro Sánchez de Soria, cardador, vecino de Cuenca, testigo: 33.

Pedro Sánchez Izquierdo, carretero, vecino de Fuentes, deudor de Álvar Garcia del Castillo y de Juan Álvarez de Montemayor: 74 .

- testigo: 75,76 .

Rodrigo de Valladolid, tejedor, vecino de Cuenca, testigo: 10.

Roy Gómez Mexía, propietario de una capilla en el convento de san Francisco de Cuenca: 2.

Roy Gutiérrez, escribano público en Huete, testigo: 67.

- procurador de Alfonso Álvarez: 69.

Ruy Fernández, "fidalgo", vecino de Cuenca, deudor de Álvar García del Castillo: 26.

Ruy Sánchez, criado de Teresa de Luna, vecino de Cuenca, testigo: 31.

San Antón, Orden de: 41.

Sancho de Jaraba, regidor de Cuenca: Ap.

Sancho de Valmaseda, vecino de Cuenca, padre de Sancho de Valmaseda: 38.

Sancho de Valmaseda, cardador, hijo de Sancho Valmaseda, vecino de Cuenca, testigo: 38.

Sancho Garcia de Molina, vecino de Cuenca, juez árbitro: 5.

Sancho Gutiérrez de Uclés, vecino de Cuenca, testigo: 57.

Sancho Sánchez de Arcas, vecino de Cuenca, deudor de Alfonso Páez de Écija: 64.

Sancho Sánchez de Guadalajara, jubonero, vecino de Cuenca, deudor de Alfonso Álvarez de Toledo: 17.

Sancho Sánchez de Herriega, vecino de Cuenca, testigo: 51.

Sancho Fernández de Huesca, apoderado de Luis Sánchez de Torralba: 27.

San Francisco, Orden de : 2.

San Juan, día de : 12.

San Miguel de septiembre: 36, 45, 65.

Santa María de agosto: 6 .

Santiago, Orden de: 68.

Teresa de Luna, poderdante de Pedro López del Monte: 31, 32.

Teresa Sánchez, viuda de Juan Sánchez Bazo: 43.

Toribio Fernández, escribano, vecino de Cuenca, testigo: 62.

Yánez Garcia, pellejero, vecino de Cuenca, padre de Fernando García de Molina: 3 